\title{
Reputation and Loan Contract Terms: the Role of Principal Customers*
}

\author{
LING CEN ${ }^{1}$, SUDIPTO DASGUPTA ${ }^{2}$, REDOUANE ELKAMHI ${ }^{3}$, and RAUNAQ S. \\ PUNGALIYA ${ }^{4}$ \\ ${ }^{1}$ Rotman School of Management and Department of Management (UTSc), University of Toronto, \\ ${ }^{2}$ HKUST Business School, Hong Kong University of Science and Technology, ${ }^{3}$ Rotman School of \\ Management, University of Toronto, and ${ }^{4}$ SKK Graduate School of Business, Sungkyunkwan \\ University
}

Abstract. Principal customers have strong incentives to screen and/or monitor suppliers to ensure supply-chain stability; consequently, the implicit certification from the existence of long-term relationships with principal customers has reputational consequences that potentially spill over to other markets. We argue that one such consequence is smaller loan spreads and looser loan covenants on bank loans, as firms that are able to hold on to principal customers longer are perceived as safer firms by banks. We address causality and endogeneity issues via a variety of tests and find consistent results. Our study suggests that non-financial stakeholders can have important effects on the decisions of financial stakeholders.

JEL Classification: G30, G21

\footnotetext{
* The authors thank an anonymous referee, Matt Billett, Murrillo Campello, Feng Chen, Kai Wai Hui, Micah Officer, Panos Patatoukas, Sean Thomas, and seminar participants at the 2014 NFA meeting for helpful comments. The authors are also grateful to the research support from Social Sciences and Humanities Research Council (SSHRC) of Canada and the GT10 research fund from SKK Graduate School of Business, Sungkyunkwan University.
} 


\section{Introduction}

For many firms, sales to a few major corporate customers account for a significant part of their total sales. Since these firms (henceforth called "suppliers") are required to disclose the presence of these major customers, it is not difficult for the market to observe the evolution of these bilateral relationships. In this study, we investigate the impact of principal customer relationships on suppliers' bank loan contracts. Specifically, we argue that a continuing longterm relationship with a principal customer provides certification of the supplier's quality, which has a favorable effect on the loan contract terms of these firms.

Customers presumably screen suppliers when they enter into a contractual relationship. However, since screening is necessarily imperfect, the relationship has the highest risk of being breached immediately after the relationship is formed, and new information becomes available. ${ }^{1}$ Importantly, by virtue of their business relationship with the supplier, principal customers are in a unique position to gain access to certain types of information that the market may not have. ${ }^{2}$ Thus, the market has to draw inferences about supplier attributes (such as the quality of its products or people etc.) that might affect the riskiness of cash flows, from the way in which the relationship with the principal customer evolves over time. In particular, a longer relationship per se conveys a positive signal about these attributes since the relationship will only continue if the new information is favorable. However, other (observable) aspects of the relationship can also change - e.g., both parties can make specific investments in the relationship (which would

\footnotetext{
${ }^{1}$ In our sample, $34 \%$ of the customer-supplier relationships are not reported after the first year and $54 \%$ of disclosed relationships last less than 3 years.

${ }^{2}$ In particular, principal customers have three major advantages over other stakeholders, such as banks, for certain types of information: 1) principal customers have a better understanding of product quality and product quantity of their suppliers than any other stakeholder; 2) principal customers can assess the financial distress risk of their suppliers by observing their speed of inventory build-ups, their willingness to accept delayed payment or to offer trade credit, which may not be revealed to other stakeholders; and 3) customer-supplier relationships usually involve frequent business interactions between the two parties, which allows principal customers to update information in a more timely manner than other stakeholders.
} 
suggest a lower likelihood of breach), or the supplier can "improve" while in the relationship with the principal customer. All of these would have a favorable effect on the supplier's loan pricing and loan contract terms. In other words, supplier firms in a longer relationship with their principal customers will be perceived as "safer" firms by the market - this perception, conditional on the state of the relationship, is what we call reputation in this paper.

Our empirical results are strongly supportive of the reputation-building or certification effect. We show that, after controlling for traditional determinants of loan spreads, the presence of a principal customer for at least three years (our definition of a "long-term" relationship) lowers supplier loan spreads by about 7.2\%. Based on the mean loan spread in our sample, this percentage change translates to an economically significant 13.6 basis point reduction for the average loan. A key challenge to the interpretation of this result is the endogeneity concern that the reduction in loan spreads associated with the presence of principal customers could be driven by common factors that are observable to both customers and lenders, but are unobservable to the empirical researcher. For example, principal customers may only be willing to do business with suppliers that have certain favorable attributes. Banks that lend to these suppliers may observe these same attributes, and are therefore willing to lend on more favorable terms.

Our first test compares spreads on loans issued in the first three years after a firm discloses a principal customer, to those issued (to the same firm) in a three year period after relationship establishment. A second test generates a placebo sample where borrowers do not have principal customers but share the same industry, credit ratings and timing of loans as borrowers in the treatment sample. These tests rule out the possibility that our results are driven by (i) time-invariant firm characteristics, (ii) time-varying industry or economy-wide characteristics; and (iii) time-varying firm characteristics that change irrespective of whether 
firms are in relationships with principal customers. We also examine measures that are mainly correlated with bank characteristics, but are unrelated to the supplier or the customer. We find that the effect of a long-term principal customer relationship on loan spreads is weaker if there is a lending relationship between the bank and the supplier, if the geographical distance between the bank and the supplier is shorter, and if the bank is larger in size. These results cannot be attributed to supplier characteristics associated with supplier risk or quality that is not controlled for in our empirical specifications but are observable to the bank, including those that change over time.

Next, we provide additional evidence that longer term customers are more likely to have supplier-relevant information that is relevant for banks, and affect loan spreads. To do so, we investigate cases where the customer and the supplier share the same (lead) bank in loan syndication. We argue that having a common link enables the bank to collect more information directly from the principal customer regarding supplier quality. We find that having any shared (lead) bank(s) in the syndicate between the principal customers and their suppliers reduces loan spreads by 16.9 (28.2) basis points, compared with loans where customers and suppliers do not share any syndicate banks. This result is consistent with the notion that customers in longer-term relationships with their suppliers are likely to have more favorable information about the latter that may not be observable to third parties.

Next, we study the effect of customer characteristics that can affect the strength of the reputation-signaling, but are unrelated to the supplier or the bank. We argue that the reputationsignaling effect should be stronger when the quality of principal customers is higher. We measure customer firm quality by considering their industry leadership, market capitalization, and credit rating. Using propensity score matching to isolate the effect of customer quality, we 
find that the average loan spread of borrowers with higher quality principal customers is lower than that of borrowers with lower quality principal customers. These differences in spreads range from 18.25 bps to 40.78 bps depending on different measures of customer quality.

One concern with the above test could be that while suppliers and customers sort on quality - i.e., higher quality customers pick higher quality suppliers - banks observe the same supplier characteristics that the customers observe, and therefore lower the loan spreads. If this were the case, we would not necessarily be establishing a channel of information flow from the presence of a long-term customer to the bank about supplier quality, which is the primary mechanism we wish to address in this paper. To mitigate this concern, we examine whether higher customer quality has a stronger effect on loan spreads when the bank's information asymmetry vis-à-vis the supplier is higher. We find very supportive evidence: customer quality lowers loan spreads when information asymmetry between the bank and the supplier is high, but not otherwise.

Finally, we study the impact of principal customer relationships on the strictness of loan covenants, which we measure using four distinct proxies that capture its different dimensions. Results based on all of these measures suggest that long-term relationships with principal customers lead not only to lower loan spreads but also looser covenants.

Our paper makes a contribution to at least two strands of the existing literature. First, our study adds new understanding of the costs and benefits for firms exposed to each other's bankruptcy risk via the supply chain. Specifically, a close economic link between customers and suppliers, while avoiding the costs of vertical integration, generates several benefits such as product customization, just-in-time inventory management, reduction of selling expenses and 
other operational synergies. It also triggers correlated supply chain risks for both parties. ${ }^{3}$ For example, when one party in the supply chain experiences major setbacks, such as bankruptcies, negative earnings shocks, or litigations, the financial distress risks diffuse along the supply chain and the operating and stock performance of their counterparties is also adversely affected (e.g., Hendricks and Singhal, 2003, 2005; Hertzel et al., 2008; Pandit, Wasley, and Zach, 2011; Kolay, Lemmon, and Tashjian, 2013; Cen et al., 2014). We argue that customer-supplier relationships, while exposing suppliers to the diffusion of significant supply chain risks, do not necessarily increase the financial costs of suppliers. Our paper shows that when the relationships with principal customers are stable over a long period, the beneficial effects of reputation-building dominate and the cost of bank financing is reduced.

Second, we add to the literature on the reputational effects of financial stakeholders, including banks and investors of public debt. Diamond (1991) suggests that firms that build reputation through bank loans lower their cost of public debt. Datta, Iskander-Datta and Patel (1999) find support for Diamond's reputation-building argument and show that the existence of a bank and firm relationship lowers the cost of public debt financing. Here, instead of financial stakeholders, we focus on the reputation-building role of long-term relationships with important non-financial stakeholders (i.e., principal customers) on the decision making of traditional financial stakeholders (i.e., banks).

Finally, our paper contributes to the literature on the effect of stakeholders on firms' financial structure (e.g., Bronars and Deere, 1991; Dasgupta and Sengupta, 1993; Titman and

\footnotetext{
${ }^{3}$ See Kalwani and Narayandas (1995) for an early study. Our results are consistent with the benefits of principal customers based on future cash flows in the literature. In spite of the traditional view that big customers tend to pressure their dependent suppliers to negotiate low prices, extract trade credit, and carry extra inventory (e.g., Galbraith, 1952; Scherer, 1970; Porter, 1974). Recent studies find that big customers help dependent suppliers to improve operation efficiency. For example, Patatoukas (2011) suggests there is a positive correlation between the customer-base concentration and the operating performance in the cross section. Cen, Dasgupta and Sen (2013) suggest that the existence of big customers improves the operating performance of a firm in time series.
} 
Wessels, 1988; Fee, Hadlock, and Thomas, 2006; Banerjee, Dasgupta, and Kim, 2008) and financial decisions (e.g., Fee and Thomas, 2004; Johnson et al., 2012; Ahern and Harford, 2014). In contrast to existing studies that consider mainly the effect of stakeholders on the debt ratio, we focus on the "microstructure” of debt, particularly loan pricing and covenants.

Our paper is organized as follows. Section 2 describes the sample characteristics and presents descriptive statistics. Sections 3 and 4 present our empirical tests and results, and Section 5 concludes the paper.

\section{Data and Summary Statistics}

\subsection{DATA SOURCE}

Our primary sample is the intersection between loan facilities from the DealScan database and publicly listed borrowers from Compustat between 1995 and $2008 .{ }^{4}$ We require that all facilities in the sample have non-missing data on loan spreads and loan maturity, as also nonmissing data on financial variables from Compustat used in the study.

Information on customer-supplier relationships are based on the Compustat segment customer file. This information is publicly available as SFAS No. 14 (before 1997) and SFAS No. 131 (after 1997) require firms to disclose the existence and sales to principal customers representing more than $10 \%$ of total firm revenues. ${ }^{5}$ However, the database reports only the name of the principal customers without identifiers. Often only the abbreviated versions of the names are reported, while sometimes the same customer is reported in a different form in different years and by different suppliers. Using manual search procedures, we identify and

\footnotetext{
${ }^{4}$ We are grateful to Michael Roberts for making the Compustat-DealScan link file publicly available.

${ }^{5}$ Some firms temporarily stopped reporting principal customers in 1998 and 1999 since it took time for them to adjust their financial reporting after the regulation had changed from SFAS 14 to SFAS 131. However, all our results remain robust after dropping observations for these two years from our sample.
} 
match customers to their Compustat identifier (i.e., GVKEY) when possible. The details of the identification and classification procedure are discussed in Banerjee, Dasgupta, and Kim (2008).

Firm characteristics, including book value of assets, book leverage, firm age and other accounting information to compute the Altman's Z-Score (1968), are retrieved from the Compustat Fundamentals Annual database. Market information, including equity volatility, market volatility, and risk-free rate, are computed based on information from CRSP Monthly and Daily Stock Files. Loan-related and bank-related information, including the loan spread, loan maturity, credit rating of loans, bank location, and bank size are retrieved from DealScan. We compute the default spread and the term spread from data series obtained from the St. Louis FRED database, and we obtain option implied market volatility (i.e., VIX), our proxy for market uncertainty, from the Chicago Board Options Exchange (CBOE). Detailed definitions of all variables are provided in Appendix A.

\subsection{MEASURES OF CUSTOMER-SUPPLIER RELATIONSHIPS AND LOAN FEATURES}

One concern in the customer-supplier dataset is that $34.71 \%$ of customer-supplier links reported in the Compustat Customer Segment File only last for one year and such short-lived links cannot be defined as a material relationship. To address this concern, we define two proxies for material customer-supplier relationships as follows. Our first proxy, Customer relationship dummy, is a dummy variable that is equal to one if a firm has at least one principal customer that works with the firm for at least three years, and zero otherwise. ${ }^{6}$ The three-year threshold is important because it is more representative of relationship establishment and signals the customer's willingness to continue the relationship, and reflects stronger incentives to monitor the supplier. Therefore, with this requirement, our measure is more consistent with the

\footnotetext{
${ }^{6}$ For parsimony, when customer relationship dummy is equal to one, we call this firm "a firm with long-term PCs" hereafter.
} 
reputation-building argument in Diamond (1991). ${ }^{7}$ We also adopt an alternative continuous measure, Relationship length, as a robustness check. This measure is defined as the saleweighted average of relationship duration for all principal customers purchasing from the supplier; thus, it is immune from any issues arising from an arbitrary cut-off period.

Loan features are captured by the following measures adopted in the literature: Loan spread is the all-in spread in basis points for the loan facility ${ }^{8}$; Covenant intensity is the total number of financial and non-financial covenants in the loan package as in Demiroglu and James (2010); and Covenant strictness, a proxy capturing the probability of covenant violation, is a financial covenant strictness measure proposed in Murfin (2012). We provide a more detailed discussion of their characteristics when we present the empirical results based on these variables.

\subsection{SUMMARY STATISTICS}

Table I reports summary statistics, including mean, standard deviation, first quartile, median, and third quartile, for the entire sample of loans in Panel A $(\mathrm{N}=12,956)$. The summary statistics suggest that $14.5 \%$ of loans in our sample are issued to borrowers with long-term relationships with principal customers, and that the sale-weighted average duration of customersupplier relationships (including zeros for those borrowers that do not have principal customers) is 1.07 years. Another interesting observation is that all major loan characteristics, including loan spread, covenant intensity and covenant strictness have a large dispersion in our sample. For example, the standard deviation of loan spread is $125.04 \mathrm{bps}$ in the full sample, which is economically large as compared with the mean of loan spreads (189.14 bps). The observed large dispersions suggest the economic importance of understanding all major determinants of loan

\footnotetext{
${ }^{7}$ This choice also eliminates firms for which the $10 \%$ threshold is reached at one point in time due to sales volatility.

${ }^{8}$ The all-in spread in basis points is the total annual spread paid by the borrower over LIBOR (or LIBOR equivalent) for each dollar of the loan facility drawn, inclusive of fees and interest payments (Graham, Li, and Qiu, 2008).
} 
characteristics. We argue in this paper that the customer-supplier relationship is an important determinant of loan characteristics for the supplier firms, which has not yet received attention in the literature.

\section{[Insert Table I Here]}

For the subsamples of loans from firms with and without long-term PCs, we provide their summary statistics in Panels $B(N=1,879)$ and $C(N=11,077)$, respectively. One can regard this partition as a univariate comparison of important characteristics for loans and borrowing firms between the two sub-groups. One obvious pattern is that borrowers with long-term PCs tend to have a lower level of covenant intensity ( 4.90 vs. 5.04 ), covenant strictness ( 0.28 vs. 0.34) and loan spread (178.12 vs. 191.01) than borrowers without such relationships. Similarly, with regards to firm characteristics, it is apparent that borrowers with long-term PCs are much smaller firms than their peers, e.g., the average book value of total assets for firms with longterm PCs is 1.56 billion, which is less than half that (i.e., 3.37 billion) of firms without long-term PCs. This difference makes our first observation about loan feature differences even more puzzling. This is because, given the extant literature, we should expect firms of smaller size and firms with a higher level of customer concentration to be riskier, leading to a higher level of covenant intensity, covenant strictness, and spread in bank loans.

As suggested by Banerjee, Dasgupta, and Kim (2008), potential suppliers are likely to lower their leverage ex-ante to attract principal customers who regard financial distress as a major disruption in their supply chains. Consistent with this notion, we observe that in spite of their smaller firm size, borrowers with long-term PCs have lower levels of book leverage (0.28 vs. 0.31$)$ and equity volatility (0.47 vs. 0.51$)$ and higher levels of Altman’s Z-Score (4.05 vs. 3.56) than their peers without long-term PCs. This may partially explain the difference in loan 
features discussed above. To rule out the possibility that the lower loan spreads, covenant strictness, and covenant intensity of firms with long-term PC relationships are mainly driven by their lower leverage compared to their peers without long-term PC relationships, we incorporate lagged leverage and financial distress measures as controls in our regression specifications.

\section{[Insert Table II Here]}

Another potential concern is that compared with borrowers without principal customers, borrowers with long-term principal customer relationships may issue different types of loans. This may explain the different loan features between these two groups of borrowers, as different loan types may have different risks associated with them. To mitigate this concern, we tabulate the distribution of loan types for these two groups of borrowers in Table II. We observe almost the same distribution of loan types within the two subsamples for firms with and without longterm PC relationships. For example, in both subsamples, revolvers account for approximately $70 \%$ of all loans, while term loans type A and type B account for about $17 \%$ and $10 \%$, respectively. ${ }^{9}$ Given this similarity in distribution, we conclude that the difference in loan features between borrowers with and without long term PCs are unlikely to be driven by the difference in loan types.

\section{The Presence of Long-Term Principal Customers and Loan Spreads}

The presence of long-term PCs conveys information to outsiders, including potential lenders. Since PCs have very regular business interactions with their suppliers, their decision to remain in a long-term relationship with a supplier is a de facto certification of the quality of supplier's products and its financial stability. Given that the PC is concerned about the quality of the supplier's product and engages in screening and monitoring (in the sense of processing new

\footnotetext{
${ }^{9}$ All types of loans are defined in Panel C of Appendix A.
} 
information to determine whether to continue the relationship) ${ }^{10}$, a long-term relationship with a PC conveys the signal to potential lenders that the relationship is unlikely to be breached in the near term because the PC finds the quality unacceptable. Thus, the supplier is perceived as safe or stable and this has a favorable effect on loan pricing.

In Section 3.1, we examine the magnitude of the cost savings on private debt capital resulting from relationships with long-term PCs. Specifically, we focus on the effect of longterm PC relationships on at-issue yield spreads (over LIBOR). We address potential endogeneity issues in Section 3.2.

Our primary dependent variable is the natural logarithm of the loan spread. We follow Graham, Liu, and Qiu (2008) and choose the log transformation since the distribution of loan spreads in the sample is not normal. Specifically, unadjusted loan spreads have a skewness of 1.54 and a kurtosis of 8.71 , while the distribution of its natural logarithm is much closer to a normal distribution with a skewness of -0.66 and a kurtosis of 3.04. Customer relationship dummy is the main independent variable of our interest and we expect its coefficient to be negative and statistically significant. Note that as the dependent variable is log spreads, the coefficient can be interpreted as the percentage change in spread resulting from the relationship with long-term PCs. As discussed earlier, we also adopt a continuous measure, Relationship length, as an alternative customer-supplier relationship measure. Following previous studies on the determinants of loan spread (e.g., Graham, Li, and Qiu, 2008; Campbell and Taksler, 2003), we include variables related to loan features, borrower's firm characteristics, and market

\footnotetext{
${ }^{10}$ In the literature, monitoring is often assumed to be "active monitoring" in the sense of one party exerting influence on the other to change behavior. In our context, while it is plausible that the PC actively monitors the supplier to ensure quality and supply chain stability, this is not required for our arguments. What is required is that the PC processes more information over time, and has a credible threat of discontinuing the relationship.
} 
conditions as controls in our specifications. Standard errors in our estimations are adjusted by clustering at the year level.

Specifically, our model of loan spreads is specified as follows:

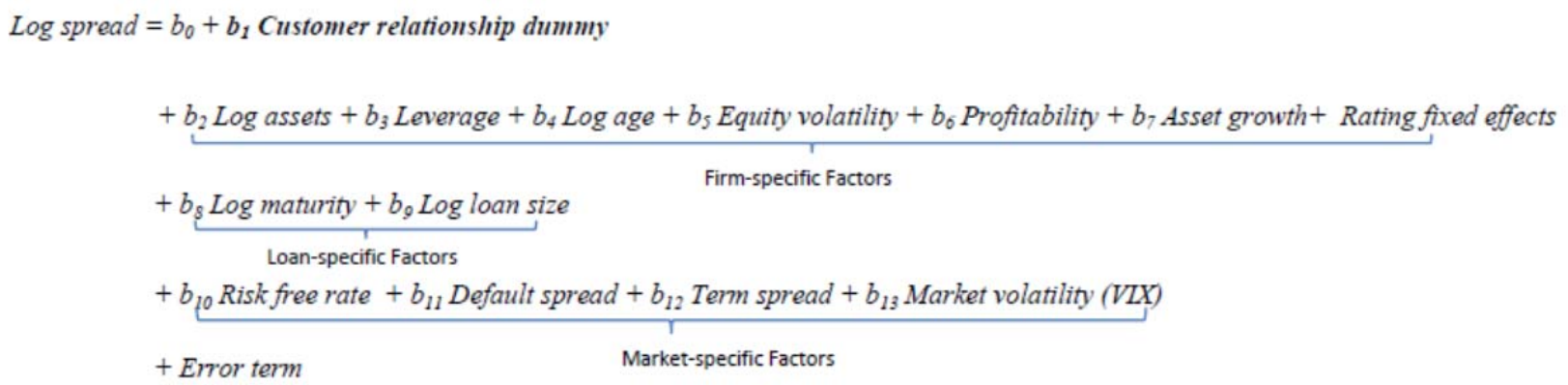

Our key variable of interest is the Customer relationship dummy, while the remaining variables are control variables. Next, we explain the reasons for including these control variables and their predicted coefficients from the prior literature.

Log assets: Larger firms have higher investor recognition, lower information asymmetry, and greater access to capital markets, which leads to a lower credit risk premium. Therefore, its coefficient is expected to be negative.

Equity volatility: In the Merton (1974) model, volatility determines the probability of exercise of the put option the bondholders sell to the equity holders. We use directly observable equity volatility to proxy for model dependent asset volatility following Campbell and Taksler (2003). The coefficient is expected to be positive.

Profitability and Asset growth: Firms with higher profitability and asset growth have a lower probability of default. Their coefficients are expected to be negative. ${ }^{11}$

\footnotetext{
${ }^{11}$ Firms that are able to hold on to their principal customers longer may enjoy higher profitability and asset growth, which would then be reflected in loan spreads. Thus, it is important to control for such observable characteristics to further examine whether relationship duration per se, affects loan spreads.
} 
Log maturity: In most cases, the longer the time to maturity, the greater the likelihood of default. Thus, the coefficient is expected to be positive.

Log loan size: Even after controlling for firm size, a larger loan size is evidence of lower information asymmetry. Moreover, larger loans may elicit greater monitoring by the lending syndicate resulting in lower spreads. For both reasons the coefficient on loan size is expected to be negative.

Firm age: More mature firms have lower information asymmetry and have greater access to the capital markets. Its coefficient is expected to be negative.

Risk free rate: In structural models (e.g., Longstaff and Schwartz, 1995) the risk-free interest rate increases the drift term of the stochastic process for asset value and reduces the probability of default. Its coefficient is expected to be negative.

Default spread: This is a measure of the default risk as well as default risk premium in the debt market, and its coefficient is expected to be positive.

Term spread: Collin-Dufresne, Goldstein, and Martin (2001) argue that a higher term spread is an indicator of improving economy as well as increasing future risk-free rates. On both counts the default risk decreases, so its coefficient is expected to be negative.

Market volatility: We measure market volatility by the VIX index. This is intended to capture the default risk in the entire economy. It is forward looking as it is inferred from option prices on the S\&P 500 index. Its coefficient is expected to be positive.

Rating fixed effects: Credit ratings are designed to be a comprehensive proxy for a firm's credit risk. Credit rating dummies are included to (1) adjust for omitted variables in the specification above, and (2) capture information unobservable to the researcher, but 
available to the rating agency owing to their privileged access to the firm's private information in the rating process.

\subsection{MAIN RESULTS}

Results in Column (3.1) of Table III suggest that in the base regression where we do not consider customer-supplier relationships, loan spread is higher 1) when borrowers are smaller, less profitable, have higher book leverage and equity volatility, and are of younger firm age; 2) when loans are of longer maturity and of smaller size; and 3) when the overall market has a higher default spread and VIX. All these results are consistent with findings in the literature. With the credit rating fixed effect, the adjusted R-square of our estimation reaches 0.519 , which suggests that our choices of independent variables are not only appropriate but also reasonably exhaustive.

\section{[Insert Table III Here]}

Column (3.2) in Table III shows that, after controlling for known determinants of loan spreads discussed above, the Customer relationship dummy has an estimated coefficient of 0.072, which is statistically significant at the $5 \%$ level. This suggests that a long-term relationship with PCs is associated with a reduction in loan spreads by about $7.2 \%$. Given that the average loan spread in our sample is $189.14 \mathrm{bps}$ as shown in Table I, this percentage change can be translated into a reduction of 13.62 bps in loan spreads, which is economically meaningful for borrowers.

We replace our discrete measure of long-term relationships with PCs, the Customer relationship dummy, with an alternative continuous measure, Relationship length, in our estimation reported in Column (3.3). As mentioned earlier, the advantage of Relationship length is that it avoids the arbitrary cutoff level in constructing indicator variables. Results based on 
Relationship length, as presented in Column (3.3), confirm our primary findings, i.e., the coefficient of Relationship length is also negative and statistically significant at the $5 \%$ level. The coefficient of Relationship length is -0.016 , suggesting that a one-year increase in Relationship length is associated with a $1.6 \%$ reduction in loan spreads. In other words, ceteris paribus, the loan spread of a borrower with a five-year sales-weighted duration in relationship with PCs is lower than that of a peer firm without any PC relationships by $15.13 \mathrm{bps}$. It is worth mentioning that we obtain this significant reduction in loan spreads, both statistically and economically, after controlling for firm and loan characteristics, credit ratings, as well as for overall market conditions.

If long-term principal customer relationships do play a certification role, we would expect that such a role becomes more important in times of greater market uncertainty. Given the cost of information production increases with market uncertainty, we expect the reduction in spread for suppliers to be more significant under more uncertain market conditions where the reputation-building effects are more valuable. Following this premise, we examine whether the favorable impact of principal customer relationships on loan spreads is magnified during periods of greater market uncertainty. Our proxy for market uncertainty is the VIX index, well-known in the popular press as "the fear index". The VIX index represents the implied market volatility from S\&P 500 stock index options. We define a period to have a high market uncertainty using a high VIX dummy, which is set to one when VIX is in its top quartile in time series and zero otherwise (i.e., high values of VIX denote high implied market volatility). Regressions reported in Columns (3.4) and (3.5) in Table III repeat our analyses reported in Columns (3.2) and (3.3) with an additional interaction term between the customer relationship proxies and the high VIX dummy. We find that the interaction terms in Columns (3.4) and (3.5) are both negative and 
statistically significant at the $1 \%$ level. This result is consistent with our conjecture that principal customer relationships are especially valuable signaling and monitoring devices during periods of high market stress.

\subsection{ADDRESSING ENDOGENEITY}

The results in Section 3.1 show a strong correlation between the existence of principal customers and the reduction in loan spreads. However, one major endogeneity concern in our setting is that unobservable common factors that are important to both the customer's and the lender's evaluation of supplier creditworthiness can bias our results. In particular, it is possible that banks observe the same supplier characteristics that the customers observe (but the empirical researcher does not), and therefore lower the loan spreads and soften loan contract terms. If this were the case, we would not necessarily be establishing a channel of information flow from the presence of a long-term PC to the bank about supplier quality, which is the crux of the reputation-building argument. We address this endogeneity issue in the next series of tests.

\section{2.a. Relationship Establishment}

In this section, we propose tests that center on the establishment of customer-supplier relationships. We define "relationship establishment" to occur when a firm reports a principal customer as contributing to at least $10 \%$ of its sales for three consecutive prior periods. We denote the year of "relationship establishment" by year $t$. Following this definition, the "preestablishment period" is the three-year period before the relationship establishment, i.e., after suppliers first report the principal customer but before the relationship establishment, or from year $t-3$ to year $t-1$. Similarly, the "post-establishment period" is defined as the period after the relationship establishment (i.e., after year t). To make the pre-establishment period and the postestablishment period comparable, we only examine the "post-establishment period" from year $t$ 
to year $t+2$. In our tests, we pair the latest loan in the pre-establishment period and the earliest loan in the post-establishment as defined above into one group.

Since we examine the change in loan spreads for the same firm around relationship establishment, this test design rules out the possibility that our result can be driven by timeinvariant firm characteristics. More importantly, this test design allows us to avoid the endogeneity concern that our effect is driven by the firm characteristics of suppliers that customers pay attention to in the selection process. It is crucial to point out here that a supplier has already been chosen by its principal customer in the pre-establishment period. We argue that if principal customers pick suppliers based on supplier characteristics that the principal customer and the bank both observe, then loan spreads in the pre-establishment period should already reflect that information. Therefore, we should not be able to observe the difference in loan spreads between loans in the pre-establishment period and loans in the post-establishment period. If, on the other hand, banks rely on the implicit certification provided by principal customers in pricing the loans, such an effect is more likely to show up later in the relationship, since a longer relationship is a clearer signal to the banks that the supplier has met the customer's standards for quality, reliability, and bankruptcy risk.

\section{[Insert Table IV Here]}

We start with tests examining the difference in raw loan spreads between loans issued in the pre-establishment period versus those issued in the post-establishment period. The first Column (4.1) in Table IV reports the regression result with the logarithm of loan spread as the dependent variable, and an indicator variable "After establishment" (that equals one if the loan is issued in the post-establishment period, and zero if the loan is issued in the pre-establishment period) as the key independent variable. Consistent with our argument, Column (4.1) shows that 
loan spreads for the average firm decrease $12.1 \%$ after relationship establishment, and this effect is statistically significant at the $5 \%$ level.

Although our result in Column (4.1) is not likely driven by the selection issue mentioned above, it can be potentially vulnerable to the following two possibilities. First, the reduction of loan spreads can be driven by common trends in the entire economy or particular industries; and, second, it can be driven by unobservable and time-varying firm characteristics that are not in our control set and that change over time independently of customer-supplier relationships for all firms. We address these concerns with two additional tests as follows.

In the first test, we construct a placebo sample for the treatment sample examined above and show that our result in the treatment sample does not hold in the placebo sample. Specifically, we match each pair of loans in the treatment sample (i.e., the one used to produce results in Column (4.1)) by all candidate pairs of "placebo" loans. Paired loans in the placebo sample must have the following characteristics: i) the borrower in the placebo sample must have one loan corresponding to the pre-establishment period and at least one loan corresponding to the post-establishment period of the matched pair of loans in the treatment sample; again, we take the latest loan in the pre-establishment period and the earliest loan in the post-establishment period to form the pair of loans in the placebo sample; ii) all borrowers in the placebo sample must have no principal customers in both pre- and post-establishment periods; iii) the borrowers in the placebo sample must belong to the same Fama-French 48 industry as the matched borrowers in the treatment sample; and iv) for the pre-establishment periods, the loans in the placebo sample must have the same credit rating as the matched loans in the treatment sample.

For each pair of loans in the treatment sample, we randomly draw a pair of loans in the candidate placebo sample. We pool all randomly picked placebo loan pairs together as a placebo 
sample. We run the same test reported in Column (4.1) in the pooled placebo sample by resampling 1000 times. As reported in Column (4.2), the mean and standard deviation of 1000 coefficients of the key independent variable, After establishment, are 0.010 and 0.033 for the placebo samples. More importantly, we find that only 11 out of these 1000 coefficients for After establishment are both negative and statistically significantly at the 5\% level. None of these 1000 coefficients are larger than the coefficient of After establishment (i.e.-0.121,) in the treatment sample. Since we ensure that loans in the treatment sample and the placebo sample have similar issuance timing, industry specification and credit ratings, our results from the placebo test suggest that the loan reduction we observe in Column (4.1) cannot be explained by a common trend in the economy, specific industries, credit rating groups and other time-varying unobservable factors that are not associated with customer-supplier relationships.

In the second test, we adjust the raw loan spread in the treatment sample by the mean loan spread in a benchmark sample. Similar to the placebo sample, we require that the borrowers of loans in the benchmark sample do not experience any relationship establishment from year $t$-3 to $t+2$, belong to the same Fama-French 48 industry, and have the same credit rating as the borrowers in the treatment sample. While most requirements are similar, the placebo sample and the benchmark sample differ in two ways. First, while the borrowers in the placebo sample must have at least one loan in the pre-establishment sample and at least one loan in the postestablishment sample, we do not impose this requirement for loans in the benchmark sample; second, while borrowers in the treatment sample and the benchmark sample get loans in the same year, we only require borrowers in the treatment sample and the placebo sample have loans in the same pre-establishment period and post-establishment period. Note that, since we take the difference between the loan spread for the treatment firm and the mean loan spread of the 
benchmark group, the result based on the adjusted loan spread are essentially in the spirit of a difference-in-difference test.

The result of this robustness test is reported in Column (4.3). We observe that, after adjusting for loan spreads of benchmark groups, our effect remains significant in term of both economic magnitude and statistical power.

To summarize, the test reported in Column (4.1) suggests that our results are not driven by time-invariant unobservable common factors that affect both the establishment of customersupplier relationships and loan spreads. In addition, the tests reported in Columns (4.2) and (4.3) suggest that our results can neither be explained by time-varying unobserved firm characteristics unrelated to the principal customer nor by common trends in the entire economy or specific industries that affect loan spreads. ${ }^{12}$

Our results, however, could reflect time-varying relationship characteristics that could inform the market about the likelihood of relationship continuation and the riskiness of the supplier's future cash flows. To the extent that these relationship effects are observable, the lower spreads enjoyed by the suppliers could reflect favorable changes in relationship attributes. Thus, even though the relationship would only last longer if the net effect of such changes were positive, it is possible that it is these relationship attributes, and not the relationship duration per se, that affects spreads. To the extent, however, that not all relevant relationship attributes are observable to outsiders, duration would still matter. To partially control for changing relationship attributes, our regressions in Table IV have already controlled for past profitability and asset growth of the supplier. In the next section we detail additional tests in a difference-in-difference

\footnotetext{
${ }^{12}$ We get very similar results when we compare loans issued after three years to the latest loan issued before the customer was first reported. Finally, we find loan spreads to be higher after a relationship is terminated than those issued three years prior to termination. In all these tests, we control for observable supplier firm characteristics that could reflect the effect of addition or termination of principal customer relationships. These results are not reported here but available on request.
} 
setting, to establish that duration conveys information about attributes not observable to third parties to the relationship.

\section{2.b. Information Asymmetry between Banks and Suppliers}

To establish that relationship duration conveys information in addition to relationship attributes that are observable to the market but not to the empirical researcher, we employ three measures that are likely to be correlated with potential information gaps between the bank and the borrower. If not all salient attributes are readily observable to third parties, we expect the presence of a long-term relationship per se to play a more important role when the information gap is likely to be larger.

Our first proxy is whether the bank has a prior lending relationship with the borrowers, based on an assumption that the bank faces greater information asymmetry for new loans rather than relationship loans. Second, we measure the geographical proximity of the bank's headquarter to that of the borrower. Here we argue that banks that are geographically distant from the borrower face greater information asymmetry than those that are closer to the borrower. Third, we consider the size of the bank and its experience in the syndicated lending market. We claim that small banks with less experience in the syndicated lending market face greater information asymmetry compared to large banks that have more resources for monitoring and screening. All three measures above are related to the characteristics of lending banks and are not likely to affect or to be affected by the customer-supplier relationships. Therefore, the different results across partitioned groups are unlikely to be driven by unknown common factors for both customer-supplier relationships and loan spreads.

[Insert Table V Here] 
We repeat the test reported in Column (3.2) of Table III in partitioned samples based on these three measures of information asymmetry between banks and suppliers above. Our results are reported in Table V. Under all measures, we find that the existence of principal customers is associated with a larger reduction in loan spreads when there exists a higher level of information asymmetry between banks and suppliers. For example, under the measure based on prior relationship between banks and borrowers, the coefficient of Customer relationship dummy is 0.100 in the sub-sample where banks have no prior lending relationships with borrowers ${ }^{13}$. This coefficient is statistically significant at the $1 \%$ level. In the sub-sample where banks have prior lending relationships with borrowers, this coefficient is -0.047 , which is not statistically different from zero. Our test also suggests that the difference of these two coefficients is statistically significant at the $5 \%$ level.

\section{2.c. Do Customers Possess Salient Information about the Supplier?}

In this section, we provide evidence consistent with the notion that customers possess information that is relevant to the banks that lend to the suppliers and affects loan spreads, and that this effect is stronger for longer-term customer-supplier relationships. We examine a special case where the banks of the suppliers also have a prior lending relationship with the principal customer. Banks in existing relationships with customers can become more informed about the supplier via several different channels - for example, through timely information about suppliers from principal customers, or the customers' own plans involving the supplier. We expect such information to be positive when the relationship between the supplier and customer has lasted longer. Therefore, the hypothesis is that suppliers that share a common bank with their principal

\footnotetext{
${ }^{13}$ We define a lending relationship to exist if the bank led a loan for the supplier in the past five years. We use the five year cutoff as the median loan in our sample has a maturity of five years. Our results are qualitatively and inferentially similar with a three year cutoff.
} 
customers would enjoy lower spreads relative to those who do not, but only if the relationship is long-term.

In this analysis, we split the sample of firms that have principal customer relationships into two groups based on whether the customer and the supplier in a relationship have a common bank in the loan syndicate, i.e., shared bank group vs. non-shared bank group. We employ the following matching procedure to compare the two groups, which is similar to incorporating an interactive effect between customer-supplier relationships and common banks in a regression approach. For each loan in the shared bank group, we find a matching loan issued by a different firm in the non-shared bank group. We ensure that the matching loan is issued in the same month with the same credit rating, and the closest propensity score based on a procedure that is designed to control for standard factors that are known to affect the default component of loan spreads from Table III (i.e., log assets, asset growth, profitability, leverage, equity volatility, log loan size, log age, log maturity, term spread, risk free rate, default spread, market volatility) ${ }^{14}$.

\section{[Insert Table VI Here]}

In Panel A of Table VI, we define a common bank linkage if a customer and a supplier have had any bank(s) in common in a five-year period prior to the current loan of the supplier firm. This is admittedly an expansive definition of shared-bank relationships. In Panel B, we employ a much more restrictive definition of shared-bank relationships and define a bank linkage only when the customer and the supplier have the same lead bank for a loan issued in a five-year period prior to the current loan of the supplier firm. In addition to the mean and median loan spreads and propensity scores for the subsample of loans with and without common banking relationships, we also report mean and median values for firm leverage and equity volatility -

\footnotetext{
${ }^{14}$ The propensity score analysis is run with a caliper of 0.25 . We also conduct a likelihood ratio test for balance/bias and find that the treatment and control samples are insignificantly different from each other based on the selection parameters.
} 
two of the most robust determinants of loan spreads both empirically and theoretically (e.g., Merton, 1974; Collin-Dufresne, Goldstein, and Martin, 2001; Campbell and Taksler, 2003; Cremers et al., 2008). The results show that not only are the propensity scores very similar, but even after matching on the propensity scores, the samples are very similar in terms of leverage and equity volatility.

If there is no private information about the customer-supplier relationship transferred through the common bank channel, we should expect no significant difference in the spreads of matched loans, as they have a similar level of default risk. In Table VI, we present results for long-term principal customer relationships. The evidence in Table VI suggests that loan spreads are significantly lower for suppliers that share banks with their customers. In Panel A, we find that having any shared bank reduces loan spreads by about 16.94 basis points. In Panel B, we show that this effect is stronger, with a 28.21 basis-point reduction in loan spreads for suppliers that share lead banks with their principal customers. In an untabulated test, we find no significant difference in loan spreads, between loans to suppliers with shared banks and those without a shared bank, when the supplier-customer relationship is for less than three years.

\section{2.d. Customer Quality}

Our main result shows that the existence of a long-term principal customer relationship significantly reduces bank loan spreads. The argument that the ability to hold on to a principal customer signals a dimension of firm quality that is relevant for lenders hinges crucially on the assumption that the principal customer is discriminating in terms of who it prefers to do business with. We expect that this should result in a more favorable signal if the principal customer in question is of higher quality. For example, problems with product quality and product recall may 
matter more for customers with higher reputation, or those with more to lose. Thus, loan spreads should be lower for suppliers in a long-term relationship with higher quality principal customers.

We present three measures that capture customer quality. Our first proxy for customer quality is a customer leadership measure - a dummy variable which is equal to one if the customer is ranked in the top five by sales in its Fama-French 48 industry in that year, and zero otherwise. Our second proxy is customer size - a common proxy for overall corporate impact in product and financial markets, and is measured by the customer firm's market value. Our final proxy is the customer's credit rating, which is a measure for a firm's reputation in the credit market. This measure is particularly relevant in our setting as we focus on bank loans.

Since the tests in this section require detailed financial information on principal customers to measure customer quality, our tests are necessarily restricted to firms with public principal customers so that we can obtain information from Compustat to compute the selected measures for customer quality. ${ }^{15}$

To isolate the effect of customer quality from other factors, we rely on a matching procedure similar to the one described in the previous section. We split our sample of supplier loans into two subsamples based on above and below median values of customer quality, except for the customer leader dummy which is a binary classification based on its definition. Next, we implement a propensity score matching procedure that is designed to control for standard firm and time specific factors that are known to affect the default component of loan spreads. Finally, for each supplier loan in the low customer quality subset, we find a matched loan issued by a

\footnotetext{
${ }^{15}$ The Compustat segment database reports only the name of the customer without identifiers. While we use a careful manual procedure to match the customer name to Compustat, we are unable to match all principal customers to a firm in Compustat since some customer firms are private and our matching procedure is not always perfect. As stated in the data section, often only an abbreviated version of the name is reported, and the same customer is reported in a different form in different years and by different suppliers. Sometimes, the disclosed customer name is a subsidiary or a business segment of a firm.
} 
different supplier in the same month, with the same credit rating, and with the closest propensity score in the high customer quality subset. We compute the difference in loan spreads of this matched pair (low quality customer - high quality customer) and test the difference in mean and median spreads using the t-test and the Wilcoxon signed-rank test.

\section{[Insert Table VII Here]}

Panel A of Table VII presents results based on the customer industry leader dummy, our first proxy of customer quality. After we use a multi-variable propensity score match, we observe that the mean/median levels of leverage and volatility in the two subsamples are very similar. Moreover, as we require that the matched loans are from different borrowers with the same credit rating and issued in the same month, we ensure that the spread differences presented are driven by the differences in customer quality and not due to other factors that may affect default risk. Consistent with our conjecture, results in Panel A indicate that loans made to borrowers with industry leader customers have lower spreads than those made to firms whose customers are not industry leaders. Further, the difference of 18.25 basis points is both economically meaningful and statistically significant at the $1 \%$ level.

In Panels B and C of Table VII, we repeat the same procedure for customer size and customer credit rating. We find a similar pattern: loan spreads are significantly lower for borrowers that have high quality customers compared to those that have low quality customers. These results suggest that suppliers that are able to hold on to higher quality principal customers are viewed more favorably in the loan market.

\section{2.e. Customer Quality and Bank Information Asymmetry}

It could be argued that the results on the effect of customer quality on loan spreads reported in the previous section do not necessarily speak to the implicit certification of suppliers 
in long-term principal customer relationships, which is the focus of this paper. For example, banks could directly observe the supplier qualities that result in or are associated with the longterm the principal customer relationships. To address this issue, we next investigate whether customer quality matters more when the information asymmetry between the bank and the supplier is greater.

We proxy information asymmetry in terms of whether the bank and the supplier had a previous lending relationship. The lending bank's information asymmetry is said to be high when the bank and the borrowing firm share no prior banking relationship. We begin by splitting this sample of supplier firms into two subsamples based on various customer characteristics (i.e., whether the customer firm is an industry leader, the customer's firm size, the customer's credit rating). Next, we implement a propensity score-matching procedure similar to the one discussed in the previous two sections that is designed to control for standard firm and time specific factors that are known to affect the default component of loan spreads. Finally, for each supplier loan in the low customer quality subset, we find a matched loan issued by a different supplier in the same quarter, with the same credit rating, and with the closest propensity score in the high customer quality subset.

\section{[Insert Table VIII Here]}

As we require information on customer characteristics, we restrict our analysis to supplier firms that have publicly listed customer firms whose corporate information are available from Compustat. As a result, the number of observations in our subsamples is small. Nonetheless, for each customer quality proxy, we find that customer reputation significantly lowers loan spreads when there is no prior lending relationship between the bank and the supplier (that is, when the information asymmetry of the lending bank vis-à-vis the supplier is likely to be higher); 
however, the magnitude of the effect of customer quality on loan spreads is smaller when a prior lending relationship is present.

\section{2.f. Revolvers versus Term Loans}

Syndicated loans exhibit heterogeneity in their cash flow structures as individual loan facilities are structured in different formats (Rauh and Sufi, 2010). The two fundamental loan facility types include revolving credit lines (or "revolvers”) and term loans (“ $\mathrm{A}$ ” and "B”). Revolvers act like corporate credit cards allowing the borrower to draw down, repay, and reborrow a loan at will. On the other hand, term loans are drawn down fully at issuance and either syndicated to banks who prefer the accelerated amortization nature of these loans (Term Loan A), or to institutional investors who prefer cash flows similar to those of bonds with a final bullet payment of the principal at maturity (Term Loan B). In this section, we examine whether the impact of principal customers on loan pricing is robust to this heterogeneity of loan types.

\section{[Insert Table IX Here]}

In our first test we analyze the proportion of revolvers to total loans for supplier firms with and without principal customers. Table II illustrates that this proportion is insignificantly different at $70.3 \%$ and $69.8 \%$ respectively for the two groups. This shows that there is no evidence of a selection effect where supplier firms with principal customers have a clear preference for either revolvers or term loans. In addition, the relatively even distribution of revolvers and term loans indicates that the coefficient on the customer relationship dummy or magnitude of the effects we document are unlikely to be affected by unobserved differences in loan type.

Second, we study whether the mere provision of a revolving credit line is cheaper in the presence of a principal customer. Our proxy for the cost of loan financing is the natural 
logarithm of the all-in-drawn spread, Log(all-in drawn spread). This spread reflects the total cost to the borrower when a facility is fully drawn down and includes both fees and interest payments. However, unlike term loans, revolvers are often not fully utilized as firms strive to maintain financing flexibility (Mian and Santos, 2012). We follow Berg, Saunders, and Steffen (2014) and compute the all-in-undrawn spread which measures the minimum fee paid by the borrower for maintaining the revolver when the draw down is equal to zero. The mean (median) all-in-undrawn spread for revolvers in our sample is 33.2 (30.0) basis points, with a standard deviation of 20.3 basis points. We study determinants of the Log(all-in-undrawn spread) following the structure of our base test presented in Column (3.2) for revolvers in our sample. Our results, reported in Column (9.1), show that cost of revolving credit provision is reduced by $-5.4 \%$ in the presence of a principal customer, significant at the $1 \%$ level. It is important to note here that the magnitude of the coefficient on the customer relationship dummy with the log allin-undrawn spread (-5.4\%) parallels our main finding with the log all-in-drawn spread (-7.2\%). This finding indicates that regardless of the draw down level - zero percent or a hundred percent - the presence of a principal customer is associated with a reduced cost of borrowing for firms. Thus, our findings are robust to the fact that revolvers may or may not be drawn down at any given point. ${ }^{16}$

\footnotetext{
${ }^{16}$ Mian and Santos (2012) estimate that the average (median) loan has a draw down ratio of 57\% (66\%) using a large sample of syndicated loans from 1988-2010 from the proprietary Shared National Credit database. We employ their estimate of the draw down ratio to estimate the economic magnitude of the reduction in the all-in-drawn spread that can be attributed to the principal customer relationship at \$211,354 $(\$ 244,726)$ per year for the average revolver in our sample. Specifically, we compute a dollar gain as a product of the size of the average revolver, the average (median) draw down ratio, and the estimated basis point reduction due to the principal customer relationship. The average revolver in our sample has a size of \$278 million and an all-in-drawn spread of 171 basis points. We estimate the percentage reduction due to customer relationship in the all-in-drawn spread for revolvers to be $-7.8 \%$ (specification 9.3). Thus, the annual dollar gain for the average revolver in our sample can be estimated as $\$ 278,000,000 \times 0.57(0.66) \times(0.0171 \times-0.078)=\$ 211,354(\$ 244,726)$. As the average revolver has a stated maturity of four years, the economic magnitude over the life of the loan is potentially much larger than this estimate.
} 
Finally, we test whether our main results are driven by a particular loan type by repeating our base test using Log(all-in drawn spread) for term loans and non-term loans separately. We report these results in Columns (9.2) and (9.3). Despite the reduced power from the lower sample size, we show that the customer relationship dummy is significant in both groups. The coefficient of the customer relationship dummy is -0.055 (statistically significant at the $10 \%$ level) in the term loan sample $(n=3,459)$ and -0.078 (statistically significant at the $1 \%$ level) in the non-term loans sample $(n=9,497)$. We conduct a Chow test of differences between the two coefficients and find that the coefficient of the customer relationship dummy is insignificantly different across revolvers and term loans ( $\mathrm{p}$-value $=0.409$ ). Overall, our results in Table IX provide evidence that the impact of principal customer relationships is pervasive across term loans and revolvers, and the benefits of the relationship accrue to the borrower even when the revolver may not be in use.

\section{Principal Customer Relationships and Covenant Strictness}

Our previous analysis shows that the presence of relationships with long-term principal customers is related to a reduction in loan spreads when suppliers borrow from banks. However, a typical loan contract consists of two important components: the price of the loan, or the loan spread that we have discussed in previous sections, and the type and strictness of loan covenants. Here, loan covenants include all financial and non-financial conditions that have to be continually met by the borrowers. Therefore, a natural question that arises together with the impact of principal customer relationships on the price of loans concerns their likely impact on bank loan covenants.

In general, extant theoretical and empirical literature on loan covenants has shown that riskier borrowers receive tighter covenants (e.g., Demiroglu and James, 2010; Murfin, 2012). 
While firms prefer looser covenants for financial flexibility, banks prefer tighter covenants to prevent the risk-shifting incentive of borrowers.

\subsection{RESULTS}

We use four distinct proxies to capture different dimensions of covenant strictness. First, we consider the financial covenant strictness measure from Murfin (2012). This measure can be interpreted as the probability of technical default or financial covenant violation. In addition, the Murfin covenant strictness measure is unique in the sense that it distills multiple dimensions of covenant strictness into one value with a clear and intuitive economic meaning. Specifically, this measure accounts for scale (the number of financial covenants), current slack (distance from the threshold value), and the covariance of various covenants (multiple independent covenants are stricter than those that are highly correlated) ${ }^{17}$ One weakness of the Murfin measure is that it only considers financial covenants. Thus, we include another measure called covenant intensity inspired by Demiroglu and James (2010), which sums both financial and non-financial covenants together in a simple index. Specifically, the covenant intensity measure sums indicator variables for the non-financial covenants (i.e., collateral covenant, dividend restrictions, asset sweep, equity sweep, and debt sweep) and the financial covenants listed for the loans in DealScan. Finally, as a robustness check, we study the number of financial covenants and the number of non-financial covenants in the covenant intensity measure separately.

\section{[Insert Table X Here]}

Our main results on loan covenants are tabulated in Table X. The dependent variable in the specification reported in Column (10.1) is the Murfin covenant strictness measure. Independent variables in this specification are selected following Murfin (2012). We follow an approach similar to our loan spread tests in Section 3 and add the customer relationship dummy

\footnotetext{
${ }^{17}$ We thank Justin Murfin for generously providing code to compute his covenant strictness measure.
} 
as a key independent variable into this specification. The coefficient of the customer relationship dummy is $-3.7 \%$, which is statistically significant at the $5 \%$ level. Given that the average covenant strictness in our sample is $33 \%$, this coefficient suggests an economically significant $11.2 \%$ decline in covenant strictness for loans to suppliers with long-term principal customer relationships.

In regressions reported in Columns (10.2)-(10.4), we study the impact of principal customer relationships on the Demiroglu-James covenant intensity measure, the number of financial covenants, and the number of non-financial covenants, respectively. We adopt Poisson regressions in these tests since the dependent variables are in the form of integer counts. The coefficients of the customer relationship dummy in all specifications reported in Columns (10.2)(10.4) are significant at the $1 \%$ level. Based on the marginal effects evaluated at the mean levels of other independent variables, our results suggest a $5 \%$ reduction in covenant intensity for loans to suppliers with long-term relationships with principal customers and that the effect exists for both financial covenants and non-financial covenants.

These tests confirm our main finding that a long-term relationship with principal customers leads not only to lower loan spreads, but also to looser covenants for loans of the suppliers. More importantly, as covenants are looser for loans of supplier firms with long-term principal customer relationships, this result eliminates the concern that firms with principal customer relationships receive lower spreads as a compensation for accepting tighter covenants.

\section{Conclusion}

We suggest in this paper that the existence of long-term relationships with principal customers have reputational effects on their suppliers that spill over to other markets. Specifically, since principal customers have strong incentives to evaluate and maintain the 
stability of their supply chain through unique information channels, the existence and continuation of long-term relationships with principal customers provide a de facto certification to the suppliers as firms of higher product quality, lower default risk and higher operating stability than their peers.

We focus on how banks, another group of important stakeholders, interpret the existence of long-term relationships that their borrowers may have with principal customers when they consider issuing loans. We argue that banks "free-ride" the reputation-building effects generated by the existence of long-term relationships, which reduces the bonding and monitoring costs associated with the loan capital. We find empirical evidence consistent with this conjecture. First, after controlling for other determinants of loan spreads, the existence of long-term principal customers is associated with a significant reduction of loan spreads. Second, we find that 1) spreads are lower for loans issued in the post-establishment period than those issued in the pre-establishment period, and 2) the reduction in loan spreads associated with the existence of long-term PCs is stronger when banks face a higher level of information asymmetry. These tests help us address the endogeneity that the main effect might be driven by common factors that are observable to both customers and lenders (i.e., banks), but are unobservable by researchers. Third, we find that our main effect is stronger when customers and suppliers share the same bank in loan syndication, suggesting that certification from the principal customer is clearer for the bank when it has a direct link with the customer. Fourth, we find that the certification effect is stronger when the quality of principal customers is higher. Fifth, we show that the cost of revolving credit provision (as proxied by the all-in-undrawn spread) is also lower in the presence of a principal customer. Finally, we show that the existence of long-term relationships with principal customers is also associated with looser bank loan covenants. Overall, our results show 
that important non-financial stakeholders, such as principal customers, have important effects on the decision making of firms’ financial stakeholders. 


\section{References}

Ahern, K. and Harford, J. (2014) The importance of industry links in merger waves, Journal of Finance 69, 527-576.

Altman, E. (1968) Financial ratios, discriminant analysis, and the prediction of corporate bankruptcy, Journal of Finance 23, 589-609.

Banerjee, S., Dasgupta, S., and Kim, Y. (2008) Buyer-supplier relationships and the stakeholder theory of capital structure, Journal of Finance 63, 2507-2552.

Berg, T., Saunders, A., and Steffen. S. (2014) The total costs of corporate borrowing in the loan market: Don’t ignore the fees, Journal of Finance, forthcoming.

Bronars, S. and Deere, D. (1991) The threat of unionization, the use of debt, and the preservation of shareholder wealth, Quarterly Journal of Economics 106, 231-254.

Campbell, J. and Taksler, G. (2003) Equity volatility and corporate bond yields, Journal of Finance 58, 2321-2349.

Cen, L., Dasgupta, S., and Sen, R. (2013) Discipline or disruption? Stakeholder relationships and the effect of takeover threat, working paper, HKUST and University of Toronto.

Cen, L., Chen, F., Hou, H., and Richardson, G. (2014) Customer-supplier relationships and strategic disclosures of litigation loss contingencies, working paper, University of Toronto.

Collin-Dufresne, P., Goldstein, R., and Martin, J. (2001) The determinants of corporate credit spreads, Journal of Finance 56, 2177-2207.

Cremers, M., Driessen J., Maenhout P., and Weinbaum, D. (2008) Individual stock-option prices and credit spreads, Journal of Banking and Finance 32, 2706-2715.

Dasgupta, S. and Sengupta, K. (1993) Sunk investment, bargaining and choice of capital structure, International Economic Review 34, 203-220.

Datta, S., Iskander-Datta, M., and Patel, A. (1999) Bank monitoring and the pricing of corporate public debt, Journal of Financial Economics 51, 435-449.

Demiroglu, C. and James, C. (2010) The information content of bank loan covenants, Review of Financial Studies 23, 3700-3737.

Diamond, D. (1991) Monitoring and reputation: The choice between bank loans and directly placed debt, Journal of Political Economy 99, 689-721. 
Fee, E., and Thomas, S. (2004) Sources of gains in horizontal mergers: Evidence from customer, supplier and rival firms, Journal of Financial Economics 74, 423-460.

Fee, E., Hadlock, C., and Thomas, S. (2006) Corporate equity ownership and the governance of product market relationships, Journal of Finance 61, 1217-1251.

Galbraith, J. (1952) American capitalism: The concept of countervailing power, HoughtonMifflin, Boston.

Graham, J., Li, S., and Qiu, J. (2008) Corporate misreporting and bank loan contracting, Journal of Financial Economics 89, 44-61.

Hendricks, K. and Singhal, V. (2003) The effect of supply chain glitches on shareholder value, Journal of Operations Management 21, 501-522.

Hendricks, K. and Singhal, V. (2005) Association between supply chain glitches and operating performance, Management Science 51, 695-711.

Herztel, M., Li, Z., Officer, M., and Rodgers, K. (2008) Inter-firm linkages and the wealth effects of financial distress along the supply chain, Journal of Financial Economics 87, 374-387.

Johnson, W., Kang, J., Masulis, R., and Yi, S. (2012) Supply chain spillover effects and the interdependence of firm financing decisions, working paper, University of New South Wales and Nanyang Technological University.

Kalwani, M., and Narayandas, N. (1995) Long-term manufacturer-supplier relationships: Do they pay off for supplier firms? Journal of Marketing 59, 1-16.

Kolay, M., Lemmon, M., and Tashjian, E. (2013) Distress-related spillover effects in the supply chain: Information revelation or real economic cost? working paper, University of Utah.

Longstaff, F. A., and Schwartz, E. S., (1995) A Simple Approach to Valuing Risky Fixed and Floating Rate Debt, Journal of Finance 50, 789-820.

Merton, R. (1974) On the pricing of corporate debt: The risk structure of interest rates, Journal of Finance 29, 449-470.

Mian, A. and Santos, J. (2012) Liquidity risk, maturity management and the business cycle, working paper, University of California, Berkeley and NBER.

Murfin, J. (2012) The supply-side determinants of loan contract strictness, Journal of Finance 67, 1565-1601. 
Pandit, S., Wasley, C., and Zach, T. (2011) Information externalities in capital markets: The economic determinants of suppliers' stock price reaction to their major customers' information events, Contemporary Accounting Research 28, 1304-1343.

Patatoukas, P. (2011) Customer-base concentration: Implications for firm performance and capital markets, Accounting Review 87, 363-392.

Porter, M. (1974) Consumer behavior, retailer power and market performance in consumer goods industries, Review of Economics and Statistics 56, 419-436.

Rauh, J. and Sufi, A., (2010) Capital structure and debt structure, Review of Financial Studies 23, $4242-4280$.

Scherer, F. (1970) Industrial Market Structure and Economic Performance. Rand McNally, Chicago.

Titman, S., and Wessels, R. (1988) The determinants of capital structure choice, Journal of Finance 43, 1-19. 
Appendix A: Variable definitions

Panel A: Firm and Loan Characteristics

\begin{tabular}{|c|c|}
\hline Variable & Definition \\
\hline Age & Age of the firm computed using the first listing year on Compustat. \\
\hline Asset growth & $\begin{array}{l}\text { Total asset (AT) growth is defined as the percentage growth in assets } \\
\text { with respect to the prior year. }\end{array}$ \\
\hline Covenant intensity & $\begin{array}{l}\text { Total number of financial and non-financial covenants in the loan } \\
\text { package computed following Demiroglu and James (2010). }\end{array}$ \\
\hline Covenant strictness & $\begin{array}{l}\text { Financial covenant strictness measure computed following Murfin } \\
\text { (2012), can be interpreted as the probability of covenant violation. }\end{array}$ \\
\hline Credit rating & $\begin{array}{l}\text { The most recent } S \& P \text { credit rating prior to the loan announcement date, } \\
\text { lower numbers represent higher default risk }(A A+=4, A A=5, \ldots, B- \\
=18, C C C+=19) \text {. }\end{array}$ \\
\hline Customer relationship dummy & $\begin{array}{l}\text { Dummy variable is equal to one if the firm has at least one principal } \\
\text { customer relationship over three years. }\end{array}$ \\
\hline Default spread & $\begin{array}{l}\text { Difference between yield of BAA rated corporate bonds and AAA rated } \\
\text { corporate bonds as of the loan facility start date. }\end{array}$ \\
\hline Equity volatility & $\begin{array}{l}\text { Volatility of daily returns is computed using } 254 \text { day period ending one } \\
\text { day before the loan facility start date. }\end{array}$ \\
\hline Leverage & $\begin{array}{l}\text { (Total long term debt + Total debt in current liabilities) / Total assets. } \\
\text { (DLTT+DLC)/AT }\end{array}$ \\
\hline Loan spread (all-in-drawn) & $\begin{array}{l}\text { The total annual spread paid by the borrower over LIBOR (or LIBOR } \\
\text { equivalent) for each dollar of the loan facility drawn, inclusive of fees } \\
\text { and interest payments. }\end{array}$ \\
\hline Loan spread (all-in-undrawn) & $\begin{array}{l}\text { The sum of the facility fee and the commitment fee following Berg, } \\
\text { Saunders, and Steffen (2014). Proxy for the cost of a revolving credit } \\
\text { loan when its drawdown is equal to zero. }\end{array}$ \\
\hline Market volatility & $\begin{array}{l}\text { Volatility index computed by the CBOE that captures market volatility } \\
\text { implied from S\&P } 500 \text { options. }\end{array}$ \\
\hline Maturity & Difference between facility start and end dates in months. \\
\hline $\begin{array}{l}\text { Number of financial } \\
\text { covenants }\end{array}$ & Number of financial covenants for the loan package listed in DealScan. \\
\hline Number of other covenants & $\begin{array}{l}\text { Number of non-financial negative covenants for the loan package listed } \\
\text { in DealScan. }\end{array}$ \\
\hline Profitability & $\begin{array}{l}\text { Profitability (past) is defined as net income (NI) scaled by total assets in } \\
\text { the prior year. }\end{array}$ \\
\hline Rated dummy & Equals one if firm is rated by S\&P, and zero otherwise. \\
\hline Relationship length & $\begin{array}{l}\text { Sale-weighted average relationship duration of all principal customers } \\
\text { working with the supplier. }\end{array}$ \\
\hline Risk free rate & Two-year constant maturity Treasury rate. \\
\hline Term spread & $\begin{array}{l}\text { Slope of the yield curve as of the loan facility start date. } \\
10 \text { year - } 2 \text { year constant maturity treasury yield }\end{array}$ \\
\hline Z-score & Altman’s Z-score measure for default risk. \\
\hline
\end{tabular}


Panel B: Description of Non-Financial Covenants

\begin{tabular}{ll}
\hline \multicolumn{1}{c}{ Variable } & Definition \\
\hline Capex covenant & $\begin{array}{c}\text { This covenant limits the amount of aggregate capital expenditures that can } \\
\text { be undertaken by the borrower during a fiscal quarter or year. } \\
\text { This covenant ensures that the loan is backed by adequate collateral which } \\
\text { can be transferred to the lender in case of default. } \\
\text { This covenant limits the magnitude and type of corporate payouts in the } \\
\text { form of dividends and repurchases. } \\
\text { Thividend covenant } \\
\text { Asset sweep } \\
\text { first be used to pay down the loan. } \\
\text { This covenant requires that a part of the proceeds from debt offerings } \\
\text { should first be used to pay down the loan. } \\
\text { This covenant requires that a part of the proceeds from equity offerings } \\
\text { should first be used to pay down the loan. }\end{array}$ \\
\hline
\end{tabular}

\section{Panel C: Type of Loans}

\begin{tabular}{|c|c|}
\hline Variable & Definition \\
\hline Revolvers & $\begin{array}{l}\text { Revolving loan facilities are like corporate credit cards that can be drawn } \\
\text { down and repaid at will during the term of the loan. }\end{array}$ \\
\hline Term Loan A & Amortizing term loan tranches typically held by banks. \\
\hline Term Loan B & $\begin{array}{l}\text { Term loan tranches structured specifically for institutional lenders to have } \\
\text { bullet payments at the end of the term. }\end{array}$ \\
\hline Acquisition Facilities & Financing intended to pay for acquisitions or related expenses. \\
\hline Bridge Loans & $\begin{array}{l}\text { Short term financing that is designed to cover shortfalls prior to asset sales, } \\
\text { bond offerings, stock offerings, etc. }\end{array}$ \\
\hline Other Loans & $\begin{array}{l}\text { Other infrequently used loan types not listed above such as letters of credit, } \\
\text { leases, note issuance facilities, etc. }\end{array}$ \\
\hline
\end{tabular}




\section{Table I. Summary Statistics}

This table reports the summary statistics for firm and loan characteristics in our sample. Our full sample, presented in Panel A, includes all COMPUSTAT firms that issue bank loans (as recorded by DealScan) from 1995 to 2008. Panels B and C compare these summary statistics between firms with principal customer relationships and firms without principal customer relationships. Detailed definitions of these variables are provided in Panel A of Appendix A.

\begin{tabular}{lrrrrrr}
\hline Panel A: Full sample & \multicolumn{1}{c}{ N } & Mean & Std. Dev. & Q1 & Median & Q3 \\
\hline Covenant intensity & 12,956 & 5.019 & 2.407 & 3.000 & 5.000 & 7.000 \\
Covenant strictness & 9,215 & 0.330 & 0.350 & 0.004 & 0.200 & 0.587 \\
Number of financial covenants & 12,956 & 2.498 & 1.079 & 2.000 & 2.000 & 3.000 \\
Number of other covenants & 12,956 & 2.521 & 1.732 & 1.000 & 2.000 & 4.000 \\
Loan spread (bps) & 12,956 & 189.141 & 125.036 & 92.500 & 175.000 & 250.000 \\
Loan maturity (Months) & 12,956 & 47.983 & 22.409 & 36.000 & 57.000 & 60.000 \\
Loan size (\$M) & 12,956 & 308.110 & 697.707 & 45.000 & 125.000 & 300.000 \\
Customer relationship dummy & 12,956 & 0.145 & 0.352 & 0.000 & 0.000 & 0.000 \\
Relationship length (Years) & 12,956 & 1.070 & 2.297 & 0.000 & 0.000 & 1.000 \\
Total assets (\$B) & 12,956 & 3.103 & 10.202 & 0.211 & 0.677 & 2.117 \\
Asset growth & 12,956 & 0.261 & 0.605 & -0.007 & 0.089 & 0.279 \\
Profitability & 12,956 & 0.030 & 0.093 & 0.005 & 0.038 & 0.074 \\
Leverage & 12,956 & 0.305 & 0.225 & 0.147 & 0.285 & 0.425 \\
Equity volatility & 12,956 & 0.507 & 0.263 & 0.326 & 0.448 & 0.616 \\
Age (Years) & 12,956 & 18.721 & 15.658 & 7.000 & 12.000 & 29.000 \\
Z-score & 12,956 & 3.630 & 4.589 & 1.716 & 2.817 & 4.398 \\
Risk free rate (\%) & 12,956 & 4.181 & 1.618 & 3.010 & 4.510 & 5.660 \\
Default spread (\%) & 12,956 & 0.937 & 0.452 & 0.680 & 0.870 & 1.010 \\
Term spread (\%) & 12,956 & 0.819 & 0.877 & 0.090 & 0.440 & 1.600 \\
Market volatility (VIX) & 12,956 & 20.821 & 7.693 & 15.060 & 20.055 & 24.370 \\
\hline
\end{tabular}


(Table I Continued)

\begin{tabular}{|c|c|c|c|c|c|c|}
\hline \multicolumn{7}{|c|}{ Panel B: Firms with principal customer relationships } \\
\hline & $\mathbf{N}$ & Mean & Std. Dev. & Q1 & Median & Q3 \\
\hline Covenant intensity & 1,879 & 4.904 & 2.198 & 3.000 & 4.000 & 7.000 \\
\hline Covenant strictness & 1,376 & 0.284 & 0.332 & 0.000 & 0.139 & 0.510 \\
\hline Number of financial covenants & 1,879 & 2.445 & 0.964 & 2.000 & 2.000 & 3.000 \\
\hline Number of other covenants & 1,879 & 2.459 & 1.686 & 1.000 & 2.000 & 4.000 \\
\hline Loan spread (bps) & 1,879 & 178.118 & 119.055 & 87.500 & 150.000 & 250.000 \\
\hline Loan maturity (Months) & 1,879 & 50.097 & 21.221 & 36.000 & 60.000 & 60.000 \\
\hline Loan size $(\$ M)$ & 1,879 & 236.265 & 412.098 & 40.000 & 100.000 & 275.000 \\
\hline Relationship length (Years) & 1,879 & 5.648 & 3.062 & 3.343 & 4.901 & 6.578 \\
\hline Total assets (\$B) & 1,879 & 1.555 & 3.303 & 0.160 & 0.500 & 1.530 \\
\hline Asset growth & 1,879 & 0.241 & 0.496 & 0.014 & 0.118 & 0.283 \\
\hline Profitability & 1,879 & 0.044 & 0.090 & 0.014 & 0.047 & 0.086 \\
\hline Leverage & 1,879 & 0.279 & 0.204 & 0.130 & 0.266 & 0.394 \\
\hline Equity volatility & 1,879 & 0.472 & 0.220 & 0.312 & 0.420 & 0.577 \\
\hline Age (Years) & 1,879 & 17.919 & 13.891 & 7.000 & 12.000 & 25.000 \\
\hline Z-score & 1,879 & 4.050 & 4.213 & 2.096 & 3.146 & 4.928 \\
\hline Risk free rate (\%) & 1,879 & 4.542 & 1.538 & 3.120 & 4.730 & 5.720 \\
\hline Default spread (\%) & 1,879 & 0.891 & 0.524 & 0.640 & 0.690 & 0.950 \\
\hline Term spread (\%) & 1,879 & 0.587 & 0.695 & 0.090 & 0.390 & 0.980 \\
\hline Market volatility (VIX) & 1,879 & 19.960 & 7.672 & 14.260 & 19.320 & 23.440 \\
\hline \multicolumn{7}{|c|}{ Panel C: Firms without principal customer relationships } \\
\hline & $\mathbf{N}$ & Mean & Std. Dev. & Q1 & Median & Q3 \\
\hline Covenant intensity & 11,077 & 5.039 & 2.440 & 3.000 & 5.000 & 7.000 \\
\hline Covenant strictness & 7,839 & 0.338 & 0.353 & 0.005 & 0.213 & 0.603 \\
\hline Number of financial covenants & 11,077 & 2.507 & 1.097 & 2.000 & 2.000 & 3.000 \\
\hline Number of other covenants & 11,077 & 2.532 & 1.740 & 1.000 & 2.000 & 4.000 \\
\hline Loan spread (bps) & 11,077 & 191.011 & 125.932 & 100.000 & 175.000 & 262.500 \\
\hline Loan maturity (Months) & 11,077 & 47.624 & 22.586 & 35.000 & 55.000 & 60.000 \\
\hline Loan size $(\$ M)$ & 11,077 & 320.297 & 734.547 & 50.000 & 125.000 & 310.000 \\
\hline Total assets (\$B) & 11,077 & 3.365 & 10.927 & 0.226 & 0.708 & 2.269 \\
\hline Asset growth & 11,077 & 0.264 & 0.622 & -0.010 & 0.084 & 0.277 \\
\hline Profitability & 11,077 & 0.028 & 0.094 & 0.003 & 0.037 & 0.072 \\
\hline Leverage & 11,077 & 0.310 & 0.228 & 0.150 & 0.289 & 0.430 \\
\hline Equity volatility & 11,077 & 0.512 & 0.269 & 0.328 & 0.454 & 0.623 \\
\hline Age (Years) & 11,077 & 18.857 & 15.935 & 6.000 & 12.000 & 30.000 \\
\hline Z-score & 11,077 & 3.559 & 4.646 & 1.662 & 2.736 & 4.327 \\
\hline Risk free rate (\%) & 11,077 & 4.120 & 1.623 & 3.010 & 4.510 & 5.560 \\
\hline Default spread (\%) & 11,077 & 0.945 & 0.438 & 0.680 & 0.900 & 1.010 \\
\hline Term spread (\%) & 11,077 & 0.859 & 0.898 & 0.090 & 0.490 & 1.870 \\
\hline Market volatility (VIX) & 11,077 & 20.967 & 7.687 & 15.280 & 20.220 & 24.560 \\
\hline
\end{tabular}




\section{Table II. Types of Loans}

This table reports the distribution of loan types in our sample. Our sample includes all loans issued by COMPUSTAT firms between 1995 and 2008. The definition for the loan types is provided in Panel C of Appendix A.

\begin{tabular}{|c|c|c|c|c|}
\hline & \multicolumn{2}{|c|}{ Firms without customer relationships } & \multicolumn{2}{|c|}{ Firms with customer relationships } \\
\hline & Number & \% Frequency & Number & \% Frequency \\
\hline Revolvers & 7,730 & 69.78 & 1,321 & 70.30 \\
\hline Term Loan A & 1,803 & 16.28 & 335 & 17.83 \\
\hline Term Loan B (Institutional) & 1,145 & 10.34 & 176 & 9.37 \\
\hline Acquisition Facilities & 203 & 1.83 & 18 & 0.96 \\
\hline Bridge Loans & 154 & 1.39 & 20 & 1.06 \\
\hline Other Loans & 44 & 0.38 & 9 & 0.48 \\
\hline Total & 11,077 & 100.00 & 1,879 & 100.00 \\
\hline
\end{tabular}




\section{Table III. Loan Spreads and Principal Customer Relationships}

This table examines the effect of principal customer relationships on loan spreads in the syndicated loan market. Our sample covers all observations with available data at the loan facility level from 1995 to 2008. Principal customer relationships are captured by two proxies. The first proxy, Customer relationship dummy, is equal to one if the firm has at least one principal customer relationship that lasts for three or more years, and zero otherwise. Relationship length, the second proxy, is a continuous variable that is computed as the sale-weighted average relationship duration of all principal customers. Columns (3.4) and (3.5) also report the impact of principal customer relationships on supplier loan spreads conditional on market volatility. Here, High VIX is a dummy variable that is equal to one when VIX is in the top quartile and zero otherwise. All OLS regressions include credit rating fixed

effects. T-statistics corresponding to time-cluster-adjusted standard errors are reported in the parentheses. ${ }^{* * *},{ }^{* * *}$, and ${ }^{*}$ denote statistical significance at the $1 \%, 5 \%$, and $10 \%$ levels, respectively. 
(Table III Continued)

\begin{tabular}{|c|c|c|c|c|c|}
\hline Log (spread) & $(3.1)$ & $(3.2)$ & (3.3) & $(3.4)$ & (3.5) \\
\hline \multirow[t]{2}{*}{ Customer relationship dummy } & & $-0.072^{* *}$ & & $-0.057^{*}$ & \\
\hline & & $(-2.18)$ & & $(-1.67)$ & \\
\hline \multirow[t]{2}{*}{ Customer relationship dummy $\times$ High VIX } & & & & $-0.075^{* *}$ & \\
\hline & & & & $(-2.46)$ & \\
\hline \multirow[t]{2}{*}{ Relationship length } & & & $-0.016^{* * *}$ & & $-0.013^{* *}$ \\
\hline & & & $(-3.18)$ & & $(-2.48)$ \\
\hline \multirow[t]{2}{*}{ Relationship length $\times$ High VIX } & & & & & $-0.010^{* *}$ \\
\hline & & & & & $(-2.39)$ \\
\hline \multirow[t]{2}{*}{ Log assets } & $-0.053^{* * *}$ & $-0.055^{* * *}$ & $-0.055^{* * *}$ & $-0.055^{* * *}$ & $-0.055^{* * *}$ \\
\hline & $(-4.85)$ & $(-5.03)$ & $(-5.13)$ & $(-5.05)$ & $(-5.15)$ \\
\hline \multirow[t]{2}{*}{ Asset growth } & 0.014 & 0.014 & 0.014 & 0.013 & 0.014 \\
\hline & $(1.43)$ & $(1.37)$ & $(1.38)$ & $(1.37)$ & $(1.38)$ \\
\hline \multirow[t]{2}{*}{ Profitability } & $-0.717^{* * *}$ & $-0.708^{* * *}$ & $-0.705^{* * *}$ & $-0.707^{* * *}$ & $-0.703^{* * *}$ \\
\hline & $(-7.23)$ & $(-6.94)$ & $(-6.89)$ & $(-6.96)$ & $(-6.90)$ \\
\hline \multirow[t]{2}{*}{ Leverage } & $0.478^{* * *}$ & $0.476^{* * *}$ & $0.472^{* * *}$ & $0.477^{* * *}$ & $0.473^{* * *}$ \\
\hline & $(10.45)$ & $(10.57)$ & $(10.66)$ & $(10.54)$ & (10.69) \\
\hline \multirow[t]{2}{*}{ Equity volatility } & $0.495^{* * *}$ & $0.487^{* * *}$ & $0.486^{* * *}$ & $0.487^{* * *}$ & $0.486^{* * *}$ \\
\hline & $(8.03)$ & $(8.18)$ & $(8.20)$ & (8.19) & $(8.22)$ \\
\hline \multirow[t]{2}{*}{ Log maturity } & $0.058^{* * *}$ & $0.058^{* * *}$ & $0.059^{* * *}$ & $0.058^{* * *}$ & $0.059^{* * *}$ \\
\hline & $(2.91)$ & $(2.91)$ & $(2.94)$ & $(2.92)$ & $(2.94)$ \\
\hline \multirow[t]{2}{*}{ Log loan size } & $-0.079^{* * *}$ & $-0.079^{* * *}$ & $-0.079^{* * *}$ & $-0.079^{* * *}$ & $-0.079^{* * *}$ \\
\hline & $(-6.57)$ & $(-6.53)$ & $(-6.51)$ & $(-6.52)$ & $(-6.51)$ \\
\hline \multirow[t]{2}{*}{ Log age } & $-0.024^{* *}$ & $-0.022^{*}$ & -0.019 & $-0.022^{*}$ & -0.019 \\
\hline & $(-2.08)$ & $(-1.82)$ & $(-1.57)$ & $(-1.82)$ & $(-1.57)$ \\
\hline \multirow[t]{2}{*}{ Risk free rate } & $-0.106^{* *}$ & $-0.105^{* *}$ & $-0.102^{* *}$ & $-0.106^{* *}$ & $-0.103^{* *}$ \\
\hline & $(-2.22)$ & $(-2.27)$ & $(-2.23)$ & $(-2.27)$ & $(-2.25)$ \\
\hline \multirow[t]{2}{*}{ Default spread } & $0.160^{* * *}$ & $0.163^{* * *}$ & $0.165^{* * *}$ & $0.163^{* * *}$ & $0.164^{* * *}$ \\
\hline & $(4.16)$ & $(4.46)$ & $(4.66)$ & $(4.52)$ & $(4.66)$ \\
\hline \multirow[t]{2}{*}{ Term spread } & -0.092 & -0.094 & -0.091 & $-0.096^{*}$ & -0.092 \\
\hline & $(-1.55)$ & $(-1.64)$ & $(-1.61)$ & $(-1.66)$ & $(-1.63)$ \\
\hline \multirow[t]{2}{*}{ Market volatility (VIX) } & $0.008^{* * *}$ & $0.008^{* * *}$ & $0.008^{* * *}$ & $0.008^{* * *}$ & $0.008^{* * *}$ \\
\hline & $(5.02)$ & $(5.02)$ & $(5.18)$ & $(5.58)$ & $(5.69)$ \\
\hline Rating fixed effects & Yes & Yes & Yes & Yes & Yes \\
\hline Observations & 12,956 & 12,956 & 12,956 & 12,956 & 12,956 \\
\hline Adj. R-squared & 0.519 & 0.520 & 0.521 & 0.520 & 0.521 \\
\hline
\end{tabular}




\section{Table IV. Loan Spreads and Relationship Establishment}

This table reports the impact of relationship establishment on loan spreads based on a difference-in-difference approach. Our sample covers all observations at the loan facility level from 1995 to 2008. Relationship establishment, as denoted by year $t$, is defined as when a firm has been reporting a principal customer that accounts for at least $10 \%$ of its total sales for 3 years. Accordingly, the pre-establishment period is the three-year period before the relationship establishment (i.e., after the supplier first reports the principal customer but before the relationship establishment, or from year $t-3$ to year $t-1)$ and the post-establishment period is defined as the period after the relationship establishment (i.e., after year $t$ ). To make the pre-establishment period and the postestablishment period comparable, we only examine the post-establishment period from year $t$ to year $t+2$. We pair the latest loan in the pre-establishment period and the earliest loan in the post-establishment as defined above into one group. The dependent variable in Column (4.1), $\log$ (spread), is the natural logarithm of the (all-in-drawn) loan spread. The dependent variable in Column (4.3), Adj. log(spread), is the difference of the log(spread) and the natural logarithm of the benchmark loan spread. The benchmark loan spread is the mean spread for loans issued in the same year as the loans in the treatment group (i.e., the one used to produce results in Column (4.1)) where the issuers of loans in the benchmark sample do not experience any relationship establishment from year $t-3$ to $t+2$, belong to the same Fama-French 48 industry, and have the same credit rating as the issuers in the treatment sample. After establishment is a dummy variable that equals one if the loan is issued during the post-establishment period, and zero if the loan is issued during pre-establishment period. Detailed definitions of other independent variables are provided in Appendix A. In all OLS specifications, we control for both pair fixed effects and credit rating fixed effects. In Columns (4.1) and (4.3), t-statistics corresponding to time-cluster-adjusted standard errors are reported in parentheses. $^{* * *},{ }^{* *}$, and ${ }^{*}$ denote statistical significance at the $1 \%, 5 \%$, and $10 \%$ levels, respectively.

Column (4.2) presents the result of a placebo test. In this test, we first match each pair of loans in the treatment sample (i.e., the one used to produce results in Column (4.1)) by all candidate pairs of "placebo" loans that have the following characteristics: i) the issuer in the placebo sample must have one loan corresponding to the preestablishment period, and at least one loan corresponding to the post-establishment period of the matched pair in the treatment sample; again, we take the latest loan in the pre-establishment period and the earliest loan in the postestablishment period to form pair of loans in the placebo sample; ii) all issuers in the placebo sample must have no principal customers in both pre- and post-establishment periods; iii) the issuers in the placebo sample must belong to the same Fama-French 48 industry as the matched issuers in the treatment sample; iv) for the pre-establishment period, the loans in the placebo sample must have the same credit rating as the matched loans in the treatment sample. For each pair of loans in the treatment sample, we randomly draw a pair of loans in the candidate placebo sample. After pooling all randomly picked placebo pairs of loans together, we run the same test as that reported in Column (4.1) in the pooled placebo sample. We repeat this test for 1000 times. The mean and standard deviation of 1000 coefficients for each independent variable are reported in Column (4.2). In addition, in square brackets, we also report the percentage of these 1000 coefficients that are smaller than the "true" coefficients reported in Column (4.1). 


\begin{tabular}{|c|c|c|c|}
\hline & $(4.1)$ & $(4.2)$ & (4.3) \\
\hline & \multicolumn{3}{|c|}{ Establishment } \\
\hline & Log(spread) & Log(spread) & Adjusted log(spread) \\
\hline & BASE REGRESSION & PLACEBO TEST & $\begin{array}{l}\text { BENCHMARK } \\
\text { ADJUSTED }\end{array}$ \\
\hline \multirow[t]{2}{*}{ After establishment } & $-0.121^{* *}$ & Mean:0.000; STD: 0.033 & $-0.225^{* *}$ \\
\hline & $(-2.26)$ & {$[0.0 \%]$} & $(-2.52)$ \\
\hline \multirow[t]{2}{*}{ Log assets } & $-0.227^{* *}$ & Mean:0.003: STD: 0.203 & $-0.226^{*}$ \\
\hline & $(-2.45)$ & {$[12.3 \%]$} & $(-2.03)$ \\
\hline \multirow[t]{2}{*}{ Asset growth } & -0.100 & Mean:-0.032: STD: 0.171 & -0.051 \\
\hline & $(-1.31)$ & {$[24.1 \%]$} & $(-1.09)$ \\
\hline \multirow[t]{2}{*}{ Profitability } & 0.212 & Mean:-0.489: STD: 0.754 & 0.230 \\
\hline & $(1.62)$ & {$[85.9 \%]$} & $(1.51)$ \\
\hline \multirow[t]{2}{*}{ Leverage } & $0.786^{*}$ & Mean:0.832 ; STD:0.519 & $0.833^{* *}$ \\
\hline & $(1.98)$ & {$[45.4 \%]$} & $(2.25)$ \\
\hline \multirow[t]{2}{*}{ Equity volatility } & $0.577^{* * *}$ & Mean:0.456 ; STD:0.389 & 0.332 \\
\hline & (3.63) & {$[66.0 \%]$} & $(1.36)$ \\
\hline \multirow[t]{2}{*}{ Log maturity } & 0.015 & Mean:-0.043; STD:0.051 & 0.038 \\
\hline & $(0.15)$ & {$[87.0 \%]$} & $(0.64)$ \\
\hline \multirow[t]{2}{*}{ Log loan size } & $-0.137^{* * *}$ & Mean:-0.125; STD: 0.034 & -0.057 \\
\hline & $(-3.09)$ & {$[50.8 \%]$} & $(-1.06)$ \\
\hline \multirow[t]{2}{*}{ Log age } & 0.021 & Mean:-0.151 ; STD: 0.441 & -0.168 \\
\hline & $(0.09)$ & {$[64.7 \%]$} & $(-0.60)$ \\
\hline \multirow[t]{2}{*}{ Risk free rate } & 0.003 & Mean: -0.075; STD: 0.107 & -0.026 \\
\hline & $(0.09)$ & {$[77.9 \%]$} & $(-0.33)$ \\
\hline \multirow[t]{2}{*}{ Default spread } & 0.107 & Mean: 0.079; STD: 0.160 & -0.113 \\
\hline & (1.17) & {$[57.0 \%]$} & $(-0.93)$ \\
\hline \multirow[t]{2}{*}{ Term spread } & 0.083 & Mean:-0.068; STD: 0.146 & -0.003 \\
\hline & $(1.30)$ & {$[85.6 \%]$} & $(-0.03)$ \\
\hline \multirow[t]{2}{*}{ Market volatility } & 0.002 & Mean: 0.004; STD: 0.010 & -0.009 \\
\hline & $(0.49)$ & [41.6\%] & $(-1.49)$ \\
\hline Rating fixed effects & Yes & Yes & Yes \\
\hline Pair fixed effects & Yes & Yes & Yes \\
\hline Observations & 312 & --- & 312 \\
\hline Adj. R-squared & 0.839 & 0.839 & 0.692 \\
\hline
\end{tabular}


Table V. Bank Informativeness and Loan Spreads

In this table, we repeat our loan spread tests reported in Table III in three different settings. These tests demonstrate how the role of principal customers is enhanced or moderated depending on the bank's potential information asymmetry about the firm, unrelated to any specific firm characteristics. In Panel A, we bifurcate the sample into two groups based on whether the bank had a prior lending relationship with the supplier. We define a lending relationship to exist if the bank led a loan for the supplier in the past five years. In Panel B, we study the geographical distance between the bank and supplier measured as the distance between the two headquarters in miles. This distance is measured using zip-code for the firm and the bank and is subject to data availability in Compustat and DealScan respectively. In Panel C, we study the size of the bank in the syndicated lending market measured as the dollar amount of loans led by the bank in the past five years. In Panels B and C, we split the sample into two groups based on the median value of the partitioning variable in the sample. While we keep all other independent variables in our main specification, we only report the coefficients of customer relationship dummy for parsimony. Time-cluster adjusted t-statistics are reported in round parentheses below the coefficient. Finally, we report p-values corresponding to a Chow test of differences in coefficients of the customer relationship dummy across two sub groups in square brackets in the rightmost column. ${ }^{* * *},{ }^{* *}$, and ${ }^{*}$ denote statistical significance at the $1 \%, 5 \%$, and $10 \%$ levels, respectively.

\begin{tabular}{lccc}
\hline \multicolumn{4}{l}{ Panel A: Does the bank have a prior lending relationship with the supplier? } \\
\hline $\begin{array}{c}\text { High information } \\
\text { asymmetry }\end{array}$ & $\begin{array}{c}\text { Low information } \\
\text { asymmetry }\end{array}$ & \\
\hline & $(5.1)$ & $(5.2)$ & \\
No prior relationship & Existing relationship & Difference test \\
\hline Customer relationship dummy & $-0.100^{* * *}$ & -0.047 & $-0.053^{* *}$ \\
& $(-2.61)$ & $(-1.09)$ & {$[0.050]$} \\
\hline Observations & 5,954 & 7,002 & \\
Adj. R-squared & 0.424 & 0.591 & \\
\hline
\end{tabular}

Panel B: How far is the bank from the supplier’s HQ (geographical distance)?

(5.3)

\begin{tabular}{lc} 
& Relatively far \\
\hline Customer relationship dummy & $-0.085^{*}$
\end{tabular}

$(-1.93)$

3,834

0.541

Adj. R-squared
(5.4)

Relatively near Difference test

$-0.014$

$(-0.32)$

3,849

\subsection{4}

Panel C: How large is the bank? Or how experienced is the bank in syndicated lending?

\begin{tabular}{lccc}
\hline & $(5.5)$ & $(5.6)$ & \\
& Small bank & Large bank & Difference test \\
\hline Customer relationship dummy & $-0.095^{* *}$ & -0.044 & $-0.051^{*}$ \\
& $(-2.50)$ & $(-1.37)$ & {$[0.064]$} \\
\hline Observations & 6,459 & 6,497 & \\
Adj. R-squared & 0.439 & 0.582 & \\
\hline
\end{tabular}




\section{Table VI. Loan Spreads and Shared Banks between Customers and Suppliers}

This table tests how bank linkages between customers and suppliers affect loan spreads using a matched firm approach. In this test, we split all firms that have long term principal customer relationships (relationship length greater than three years) into two groups based on whether the customer and supplier have a common bank in the loan syndicate. For each loan in the shared bank group, we find a matching loan (issued by a different firm) in the non-shared bank group which is issued in the same month with the same credit rating, and the closest propensity score based on specific factors known to affect the default component of loan spreads from Table III (i.e., log assets, asset growth, profitability, leverage, equity volatility, log loan size, log age, log maturity, term spread, risk free rate, default spread, market volatility). Panel A defines common bank linkage if the customer and supplier have any bank(s) in common in all the loans they have issued in the five years preceding the current loan issue. Panel B is more restrictive and defines a common bank linkage only if the customer and supplier share the same lead bank for any loan issued in the same time period. The mean and median differences in loan spreads between the matched pairs are tested using a t-test and the Wilcoxon signed-rank test. ${ }^{* * *},{ }^{* *}$, and ${ }^{*}$ denote statistical significance at the $1 \%$, $5 \%$, and $10 \%$ levels, respectively.

\begin{tabular}{|c|c|c|c|c|c|c|}
\hline & \multicolumn{2}{|c|}{ No shared bank } & \multicolumn{2}{|c|}{ Shared bank } & \multirow{2}{*}{$\begin{array}{l}\text { Mean } \\
\text { difference }\end{array}$} & \multirow{2}{*}{$\begin{array}{l}\text { Median } \\
\text { difference }\end{array}$} \\
\hline & Mean & Median & Mean & Median & & \\
\hline \multicolumn{7}{|c|}{ Panel A: Any bank in the syndicate in common between $t-5$ and $t(N=454)$} \\
\hline Leverage & 0.24 & 0.21 & 0.23 & 0.22 & & \\
\hline Equity volatility & 0.50 & 0.46 & 0.47 & 0.42 & & \\
\hline Propensity score & 0.35 & 0.33 & 0.38 & 0.37 & & \\
\hline Loan spread & 190.47 & 175.00 & 173.53 & 150.00 & $16.94^{* *}$ & $15.00^{* * *}$ \\
\hline \multicolumn{7}{|c|}{ Panel B: Lead bank in common between $t-5$ and $t(N=229)$} \\
\hline Leverage & 0.25 & 0.23 & 0.25 & 0.24 & & \\
\hline Equity volatility & 0.49 & 0.45 & 0.45 & 0.36 & & \\
\hline Propensity score & 0.18 & 0.17 & 0.25 & 0.20 & & \\
\hline Loan spread & 189.83 & 162.50 & 161.62 & 150.00 & $28.21^{* * *}$ & $25.00^{* * * *}$ \\
\hline
\end{tabular}


Table VII. Customer Quality and Loan Spreads

This table reports the impact of customer quality on loan spreads using a matched firm approach similar to the one employed in Table VI. As we require information on customer characteristics, we restrict our analysis to supplier firms that have publicly listed customer firms whose corporate information are available from Compustat. We begin by splitting this sample of supplier firms into two subsamples based on various customer characteristics (i.e., (a) whether the customer firm is an industry leader, (b) the customer's firm size, and (c) the customer's credit rating). Next, we implement a propensity score matching procedure that is designed to control for standard firm and time specific factors that are known to affect the default component of loan spreads from Table III (i.e., log assets, asset growth, profitability, leverage, equity volatility, log loan size, log age, log maturity, term spread, risk free rate, default spread, market volatility). Next, for each supplier loan in the low customer quality subset, we find a matched loan issued by a different supplier in the same month, with the same credit rating, and with the closest propensity score in the high customer quality subset. The mean and median differences in loan spreads between the matched pairs are tested using a t-test and the Wilcoxon signed-rank test. ${ }^{* * *},{ }^{* * *}$, and ${ }^{*}$ denote statistical significance at the $1 \%$, $5 \%$, and $10 \%$ levels, respectively.

\begin{tabular}{|c|c|c|c|c|c|c|}
\hline & \multicolumn{2}{|c|}{$\begin{array}{l}\text { Customer is not an } \\
\text { industry leader }\end{array}$} & \multicolumn{2}{|c|}{$\begin{array}{l}\text { Customer is an } \\
\text { industry leader }\end{array}$} & \multirow[t]{2}{*}{$\begin{array}{l}\text { Mean } \\
\text { difference }\end{array}$} & \multirow[t]{2}{*}{$\begin{array}{l}\text { Median } \\
\text { difference }\end{array}$} \\
\hline & Mean & Median & Mean & Median & & \\
\hline \multicolumn{7}{|c|}{ Panel A: Customer leader dummy (top 5 in sales in the industry) [n=476] } \\
\hline Customer leader & 0.00 & 0.00 & 1.00 & 1.00 & & \\
\hline Leverage & 0.20 & 0.18 & 0.20 & 0.19 & & \\
\hline Equity volatility & 0.56 & 0.49 & 0.55 & 0.49 & & \\
\hline Propensity score & 0.62 & 0.62 & 0.63 & 0.63 & & \\
\hline \multirow[t]{3}{*}{ Loan spread } & 199.63 & 175.00 & 182.63 & 150.00 & $18.25^{* * *}$ & $17.50^{* *}$ \\
\hline & \multicolumn{2}{|c|}{ Small customer size } & \multicolumn{2}{|c|}{ Large customer size } & Mean & Median \\
\hline & Mean & Median & Mean & Median & difference & difference \\
\hline \multicolumn{7}{|c|}{ Panel B: Customer size (market value in $\$$ billion) [ $n=498]$} \\
\hline Customer size & 13.04 & 9.46 & 146.59 & 120.26 & & \\
\hline Leverage & 0.20 & 0.18 & 0.20 & 0.19 & & \\
\hline Equity volatility & 0.53 & 0.48 & 0.53 & 0.46 & & \\
\hline Propensity score & 0.49 & 0.49 & 0.49 & 0.49 & & \\
\hline \multirow[t]{3}{*}{ Loan spread } & 195.09 & 175.00 & 174.72 & 150.00 & $19.71^{* * *}$ & $18.75^{* * *}$ \\
\hline & \multicolumn{2}{|c|}{ Low customer rating } & \multirow{2}{*}{\multicolumn{2}{|c|}{$\begin{array}{l}\text { High customer rating } \\
\text { Mean }\end{array}$}} & & Median \\
\hline & Mean & Median & & & difference & difference \\
\hline \multicolumn{7}{|c|}{ Panel C: Customer credit rating [ $n=458]$} \\
\hline Customer rating & $\mathrm{BBB}$ & $\mathrm{BBB}+$ & AA- & AA & & \\
\hline Leverage & 0.22 & 0.21 & 0.22 & 0.23 & & \\
\hline Equity volatility & 0.53 & 0.46 & 0.51 & 0.45 & & \\
\hline Propensity score & 0.53 & 0.52 & 0.54 & 0.54 & & \\
\hline Loan spread & 210.19 & 175.00 & 168.98 & 150.00 & $40.78^{* * *}$ & $25.00^{* * *}$ \\
\hline
\end{tabular}


Table VIII. Bank Informativeness, Customer Quality and Loan Spreads

This table reports the impact of customer quality on loan spreads using a matched firm approach, conditional on bank's potential information asymmetry about the firm measured by the existence or absence of a prior banking relationship. The lending bank's information asymmetry is said to be high when the bank and the borrowing firm share no prior banking relationship. This test can be seen as a combination of tests conducted in Table V and Table VII. We begin by splitting this sample of supplier firms into two subsamples based on various customer characteristics (i.e., (a) whether the customer firm is an industry leader, (b) the customer's firm size, and (c) the customer's credit rating). The propensity score matching procedure is identical as that described in Table V. The mean differences in loan spreads between the matched pairs are tested using a difference t-test. ${ }^{* * * *},{ }^{* *}$, and ${ }^{*}$ denote statistical significance at the $1 \%, 5 \%$, and $10 \%$ levels, respectively.

\begin{tabular}{|c|c|c|c|c|c|c|}
\hline & \multicolumn{2}{|c|}{$\begin{array}{c}\text { Bank Information } \\
\text { Asymmetry is High }\end{array}$} & \multirow{2}{*}{$\begin{array}{l}\text { Mean } \\
\text { difference } \\
{[n=66]}\end{array}$} & \multicolumn{2}{|c|}{$\begin{array}{c}\text { Bank Information } \\
\text { Asymmetry is Low }\end{array}$} & \multirow{2}{*}{$\begin{array}{l}\text { Mean } \\
\text { difference } \\
{[n=89]}\end{array}$} \\
\hline & $\begin{array}{c}\text { Non- } \\
\text { leader } \\
\text { customer }\end{array}$ & $\begin{array}{c}\text { Customer } \\
\text { is an } \\
\text { industry } \\
\text { leader }\end{array}$ & & $\begin{array}{l}\text { Non-leader } \\
\text { customer }\end{array}$ & $\begin{array}{c}\text { Customer } \\
\text { is an } \\
\text { industry } \\
\text { leader }\end{array}$ & \\
\hline \multicolumn{7}{|c|}{ Panel A: Customer leader dummy (top 5 in sales in the industry) } \\
\hline Customer leader & 0.00 & 1.00 & & 0.00 & 1.00 & \\
\hline Propensity score & 0.72 & 0.73 & & 0.72 & 0.74 & \\
\hline \multirow[t]{3}{*}{ Loan spread } & 212.46 & 172.39 & $40.07^{* *}$ & 150.53 & 150.39 & -0.13 \\
\hline & \multicolumn{2}{|c|}{$\begin{array}{c}\text { Bank Information } \\
\text { Asymmetry is High }\end{array}$} & $\begin{array}{l}\text { Mean } \\
\text { difference }\end{array}$ & \multicolumn{2}{|c|}{$\begin{array}{l}\text { Bank Information } \\
\text { Asymmetry is Low }\end{array}$} & $\begin{array}{l}\text { Mean } \\
\text { difference }\end{array}$ \\
\hline & $\begin{array}{c}\text { Small } \\
\text { customer }\end{array}$ & $\begin{array}{c}\text { Large } \\
\text { customer }\end{array}$ & {$[n=88]$} & $\begin{array}{c}\text { Small } \\
\text { customer }\end{array}$ & $\begin{array}{c}\text { Large } \\
\text { customer }\end{array}$ & {$[n=133]$} \\
\hline \multicolumn{7}{|c|}{ Panel B: Customer size (market value in \$ billion) } \\
\hline Customer size & 15.15 & 147.91 & & 22.44 & 159.40 & \\
\hline Propensity score & 0.48 & 0.50 & & 0.48 & 0.49 & \\
\hline \multirow[t]{3}{*}{ Loan spread } & 219.62 & 155.63 & $63.99^{* * *}$ & 178.12 & 155.92 & $22.20^{*}$ \\
\hline & \multicolumn{2}{|c|}{$\begin{array}{c}\text { Bank Information } \\
\text { Asymmetry is High }\end{array}$} & \multirow{2}{*}{$\begin{array}{l}\text { Mean } \\
\text { difference } \\
{[n=57]}\end{array}$} & \multicolumn{2}{|c|}{$\begin{array}{c}\text { Bank Information } \\
\text { Asymmetry is Low }\end{array}$} & \multirow{2}{*}{$\begin{array}{l}\text { Mean } \\
\text { difference } \\
{[n=138]}\end{array}$} \\
\hline & $\begin{array}{c}\text { Low } \\
\text { customer } \\
\text { rating }\end{array}$ & $\begin{array}{c}\text { High } \\
\text { customer } \\
\text { rating }\end{array}$ & & $\begin{array}{l}\text { Low } \\
\text { customer } \\
\text { rating }\end{array}$ & $\begin{array}{c}\text { High } \\
\text { customer } \\
\text { rating }\end{array}$ & \\
\hline \multicolumn{7}{|c|}{ Panel C: Customer credit quality (rating) } \\
\hline Customer rating & BBB & AA- & & BBB & AA- & \\
\hline Propensity score & 0.48 & 0.56 & & 0.49 & 0.54 & \\
\hline Loan spread & 234.56 & 185.96 & $48.60^{* *}$ & 167.46 & 145.61 & $21.85^{*}$ \\
\hline
\end{tabular}




\section{Table IX. Loan Fee, Loan Type, and Principal Customer Relationships}

In this table, we study the impact of the two major loan types in our sample (revolvers and term loans) on our analysis. As revolvers may not be drawn down, we first test whether principal customer relationships also affect the all-in-undrawn spread. The all-in undrawn spread captures the cost of providing the revolving credit line even when the draw down is zero. It is the sum of the facility fee and the commitment fee (Berg, Saunders, and Steffen (2014)). Column (9.1) presents these results. The sample size for Column (9.1) $(n=8,783)$ is slightly lower than the full sample of revolvers $(n=9,051)$ due to missing fee data in DealScan. Next, we examine whether the effect of principal customer relationships is present for both term loans (Column (9.2)) and non-term loans (Column (9.3)). The dependent variable in Columns (9.2) and (9.3) is the log (all-in-drawn) spread. Principal customer relationships are captured by a customer relationship dummy that is equal to one if the firm has at least one principal customer relationship that lasts for three or more years, and zero otherwise. All OLS regressions include credit rating fixed effects. T-statistics corresponding to time-cluster-adjusted standard errors are reported in the parentheses. ${ }^{* * *}$, ${ }^{* *}$, and * denote statistical significance at the $1 \%, 5 \%$, and $10 \%$ levels, respectively. 
(Table IX Continued)

\begin{tabular}{|c|c|c|c|}
\hline & (9.1) & (9.2) & (9.3) \\
\hline & $\begin{array}{c}\text { Log } \\
\text { (All-in undrawn spread) }\end{array}$ & $\begin{array}{c}\text { Log } \\
\text { (All-in drawn spread) }\end{array}$ & $\begin{array}{c}\text { Log } \\
\text { (All-in drawn spread) }\end{array}$ \\
\hline Loan type & Revolvers & Term Loans & Non-term loans \\
\hline \multirow[t]{2}{*}{ Customer relationship dummy } & $-0.054^{* * *}$ & $-0.055^{*}$ & $-0.078^{* * *}$ \\
\hline & $(-2.44)$ & $(-1.73)$ & $(-2.82)$ \\
\hline \multirow{2}{*}{ Log assets } & -0.002 & $-0.067^{* * *}$ & -0.061 \\
\hline & $(-0.20)$ & $(-4.13)$ & $(-5.33)^{* * *}$ \\
\hline \multirow[t]{2}{*}{ Asset growth } & 0.014 & 0.010 & 0.013 \\
\hline & $(0.90)$ & $(0.80)$ & $(1.40)$ \\
\hline \multirow[t]{2}{*}{ Profitability } & $-0.596^{* * *}$ & $-0.602^{* * *}$ & $-0.731^{* * *}$ \\
\hline & $(-9.45)$ & $(-5.83)$ & $(-8.73)$ \\
\hline \multirow[t]{2}{*}{ Leverage } & $0.451^{* * *}$ & $0.176^{* * *}$ & $0.534^{* * *}$ \\
\hline & $(11.45)$ & $(3.42)$ & (11.58) \\
\hline \multirow[t]{2}{*}{ Equity volatility } & $0.324^{* * *}$ & $0.397^{* * *}$ & 0.529 \\
\hline & $(7.10)$ & $(6.61)$ & $(9.78)^{* * *}$ \\
\hline \multirow[t]{2}{*}{ Log maturity } & $0.144^{* * *}$ & $0.054^{* *}$ & -0.014 \\
\hline & $(9.56)$ & $(2.00)$ & $(-0.79)$ \\
\hline \multirow[t]{2}{*}{ Log loan size } & $-0.083^{* * *}$ & $0.021^{*}$ & $-0.093^{* * *}$ \\
\hline & $(-8.01)$ & $(1.81)$ & $(-8.54)$ \\
\hline \multirow[t]{2}{*}{ Log age } & $-0.030^{* * *}$ & $0.021^{*}$ & $-0.026^{* *}$ \\
\hline & $(-2.95)$ & $(1.77)$ & $(-2.48)$ \\
\hline \multirow[t]{2}{*}{ Risk free rate } & -0.021 & -0.039 & $-0.114^{* * *}$ \\
\hline & $(-0.97)$ & $(-1.26)$ & $(-3.98)$ \\
\hline \multirow{2}{*}{ Default spread } & $0.165^{* * *}$ & $0.164^{* * *}$ & $0.173^{* * *}$ \\
\hline & $(6.79)$ & $(4.52)$ & $(6.10)$ \\
\hline \multirow[t]{2}{*}{ Term spread } & 0.016 & -0.017 & $-0.098^{* * *}$ \\
\hline & $(0.46)$ & $(-0.40)$ & $(-2.62)$ \\
\hline \multirow[t]{2}{*}{ Market volatility (VIX) } & $0.007^{* * *}$ & $0.007^{* * *}$ & $0.006^{* * *}$ \\
\hline & $(6.44)$ & $(5.46)$ & $(3.96)$ \\
\hline Rating fixed effects & Yes & Yes & Yes \\
\hline Observations & 8,783 & 3,459 & 9,497 \\
\hline Adj. R-squared & 0.505 & 0.280 & 0.568 \\
\hline
\end{tabular}


Table X. Covenant Strictness and Relationships with Principal Customers

This table reports the effect of principal customer relationships on loan covenant strictness. Our sample covers all observations at the loan facility level from 1995 to 2008 with available data. The customer relationship dummy is equal to one if the firm has at least one principal customer relationship over three years, and zero otherwise. We measure covenant strictness using four distinct proxies that capture its different dimensions. First, we consider the financial covenant strictness measure from Murfin (2012) that can be interpreted as the probability of covenant violation. Second, we consider the covenant intensity measure inspired by Demiroglu and James (2010) that sums indicator variables for non-financial covenants (collateral covenant, dividend restrictions, asset sweep, equity sweep, and debt sweep) and financial covenants listed for the loan in the DealScan database. Finally, we parse out the number of financial covenants and non-financial covenants and consider them separately. T-statistics (for OLS regressions) and Z-statistics (for Poisson regressions) corresponding to time-cluster-adjusted standard errors are reported in the parentheses. Marginal effects for the customer relationship dummy variable, evaluated at the mean levels of other independent variables, are enclosed in square brackets. ${ }^{* * *},{ }^{* * *}$, and ${ }^{*}$ denote statistical significance at the $1 \%, 5 \%$, and $10 \%$ levels respectively.

\begin{tabular}{|c|c|c|c|c|}
\hline & (10.1) OLS & (10.2) Poisson & (10.3) Poisson & (10.4) Poisson \\
\hline & $\begin{array}{l}\text { Covenant } \\
\text { strictness }\end{array}$ & $\begin{array}{l}\text { Covenant } \\
\text { intensity }\end{array}$ & $\begin{array}{l}\text { Number of } \\
\text { financial } \\
\text { covenants }\end{array}$ & $\begin{array}{c}\text { Number of } \\
\text { non-financial } \\
\text { covenants }\end{array}$ \\
\hline \multirow[t]{2}{*}{ Customer Relationship dummy } & $-0.037^{* *}$ & $-0.043^{* * *}$ & $-0.043^{* * *}$ & $-0.042^{* * *}$ \\
\hline & $(-2.47)$ & $(-4.65)$ & $(-4.63)$ & $(-3.03)$ \\
\hline [Marginal effect] & --- & {$[-0.202]$} & {$[-0.104]$} & {$[-0.094]$} \\
\hline \multirow[t]{2}{*}{ Log maturity } & $-0.013^{*}$ & $0.128^{* * *}$ & $0.088^{* * *}$ & $0.173^{* * *}$ \\
\hline & $(-1.78)$ & $(18.57)$ & $(14.02)$ & $(15.53)$ \\
\hline \multirow[t]{2}{*}{ Log loan size } & $-0.030^{* * *}$ & $-0.034^{* * *}$ & $-0.060^{* * *}$ & -0.008 \\
\hline & $(-4.03)$ & $(-9.38)$ & $(-16.61)$ & $(-1.48)$ \\
\hline \multirow[t]{2}{*}{ Secured loan } & $0.128^{* * *}$ & $0.453^{* * *}$ & $0.160^{* * *}$ & $0.823^{* * *}$ \\
\hline & $(14.17)$ & $(43.00)$ & $(19.08)$ & $(41.48)$ \\
\hline \multirow[t]{2}{*}{ Log \# participants } & $0.017^{*}$ & $0.074^{* * *}$ & $0.056^{* * *}$ & $0.092^{* * *}$ \\
\hline & $(1.81)$ & $(13.30)$ & $(9.43)$ & $(11.50)$ \\
\hline \multirow[t]{2}{*}{ Z-Score } & $-0.029^{* * *}$ & $-0.009^{* * *}$ & $-0.006^{* * *}$ & $-0.013^{* * *}$ \\
\hline & $(-7.90)$ & $(-7.98)$ & $(-5.38)$ & $(-7.55)$ \\
\hline \multirow[t]{2}{*}{ Z-Score squared } & $0.000^{* * *}$ & $0.000^{* * *}$ & $0.000^{* * *}$ & $0.000^{* * *}$ \\
\hline & $(3.52)$ & $(5.84)$ & $(4.73)$ & $(4.22)$ \\
\hline \multirow[t]{2}{*}{ Risk free rate } & 0.008 & $-0.029^{* * *}$ & $0.010^{* *}$ & $-0.070^{* * *}$ \\
\hline & $(0.52)$ & $(-6.11)$ & $(2.13)$ & $(-9.66)$ \\
\hline \multirow[t]{2}{*}{ Default spread } & 0.003 & $-0.056^{* * *}$ & $-0.042^{* * *}$ & $-0.072^{* * *}$ \\
\hline & $(0.12)$ & $(-5.24)$ & $(-4.04)$ & $(-4.55)$ \\
\hline \multirow[t]{2}{*}{ Term spread } & 0.019 & $-0.021^{* * *}$ & $0.039^{* * *}$ & $-0.083^{* * *}$ \\
\hline & $(0.81)$ & $(-2.88)$ & $(5.12)$ & $(-7.45)$ \\
\hline \multirow[t]{2}{*}{ Market volatility } & $0.002^{*}$ & $0.002^{* * *}$ & $0.003^{* * *}$ & 0.001 \\
\hline & $(1.84)$ & $(4.30)$ & $(6.92)$ & $(1.48)$ \\
\hline Rating fixed effects & Yes & Yes & Yes & Yes \\
\hline Observations & 9,215 & 12,956 & 12,956 & 12,956 \\
\hline Pseudo R-squared & 0.171 & 0.108 & 0.035 & 0.126 \\
\hline
\end{tabular}

